\title{
The AN2 Protein Is a Novel Marker for the Schwann Cell Lineage Expressed by Immature and Nonmyelinating Schwann Cells
}

\author{
Stephanie Schneider, ${ }^{1}$ Frank Bosse, ${ }^{2}$ Donatella D'Urso, ${ }^{2}$ Hans-Werner Müller, ${ }^{2}$ Michael W. Sereda, ${ }^{3}$ \\ Klaus-Armin Nave, ${ }^{3}$ Antje Niehaus, ${ }^{1}$ Tore Kempf, ${ }^{4}$ Martina Schnölzer, ${ }^{4}$ and Jacqueline Trotter ${ }^{1}$ \\ 1Department of Neurobiology, University of Heidelberg, 69120 Heidelberg, Germany, ${ }^{2}$ Molecular Neurobiology \\ Laboratory, Department of Neurology, Heinrich-Heine University of Düsseldorf, 40225 Düsseldorf, Germany, ${ }^{3}$ Max- \\ Planck-Institute of Experimental Medicine, Department of Neurogenetics, 37037 Göttingen, Germany, and 4 Protein \\ Analysis Facility, German Cancer Research Center, 69120 Heidelberg, Germany
}

\begin{abstract}
The expression of the $330 \mathrm{kDa}$ AN2 glycoprotein was studied in the rodent peripheral nervous system. AN2 is expressed by immature Schwann cells in vitro and in vivo and downregulated as the cells upregulate myelin genes. A subpopulation of nonmyelinating Schwann cells in the adult sciatic nerve retains expression of AN2. In rat sciatic nerve crushes, where Schwann cell numbers increase after initial axonal loss and markers of immature Schwann cells show an upregulation, no increased expression of AN2 was observed. In contrast, AN2 expression was upregulated in nerves from peripheral myelin protein-22transgenic rats, where immature Schwann cells expand without axonal loss. Furthermore, coculture with neurons upregulated
\end{abstract}

AN2 expression on Schwann cells in vitro. Polyclonal antibodies against AN2 inhibited the migration of an immortalized Schwann cell clone in an in vitro migration assay, and the purified AN2 protein was shown to be neither inhibitory nor permissive for outgrowing dorsal root ganglion neurites. AN2 is thus a novel marker for the Schwann cell lineage. Matrixassisted laser desorption/ionization time-of-flight mass spectrometry analysis of purified AN2 from early postnatal mouse brain demonstrated that AN2 is the murine homolog of the rat NG2 proteoglycan.

Key words: Schwann cells; myelination; glycoprotein; NG2 proteoglycan; regeneration; Charcot-Marie-Tooth disease type $1 \mathrm{~A}$
Schwann cells arise from the neural crest (Le Douarin et al., 1991). The Schwann cell (SC) lineage exhibits clearly defined stages characterized by specific antigenic phenotype, morphology, and survival requirements. Axonal contact regulates and is instructive for SC development (Bunge, 1993; Einheber et al., 1993; Mirsky and Jessen, 1996; Zorick and Lemke, 1996; Jessen and Mirsky, 1999). The SC precursors arise at embryonic day 12 (E12) in the mouse and are critically dependent on axonal survival factors (Jessen et al., 1994). At approximately E15, they develop into immature SCs that are less dependent on axonal signals for survival (Meier et al., 1999). During the first postnatal week, immature SCs proliferate in response to axonal signals and start to develop into myelinating or nonmyelinating SCs. The latter share the expression of many antigens with immature SCs and loosely ensheath several small-diameter axons. In addition to receiving instructions from axons, SCs and their precursors yield signals for axon survival and specialization (Davies, 1998; Vabnick and Shrager, 1998; Witt and Brady, 2000).

Several pathological situations are associated with an expansion of the immature SC population. After nerve transection or crush

Received July 26, 2000; revised Oct. 31, 2000; accepted Nov. 3, 2000.

Grant support from the Deutsche Forschungsgemeinschaft (Schwerpunkt Glia; SFB 488 and the Graduate Programme Molecular and Cellular Neurobiology) is gratefully acknowledged. J.T. was a recipient of a Hermann and Lilly-SchillingStiftung Professorship of Neuroscience. We thank Iris Bünzli-Ehret and Doris Kendel for excellent technical assistance. We thank Andreas Faissner for helpful suggestions regarding the regeneration experiments. Bernhard Ludewig and Kristin Tessmar are thanked for help with some of the initial experiments. Andrea Hellwig is acknowledged for the EM work. We thank Marianne Diers-Fenger for critical reading of this manuscript. Rüdiger Rudolf and Hans-Hermann Gerdes are gratefully acknowledged for advice on videomicroscopy.

Correspondence should be addressed to Dr. Jacqueline Trotter at the above address. E-mail: jtrotter@sun0.urz.uni-heidelberg.de.

Copyright (C) 2001 Society for Neuroscience $\quad 0270-6474 / 01 / 210920-\bullet \$ 15.00 / 0$ of mammalian peripheral nerves, regeneration ensues after axon breakdown and Wallerian degeneration. This degeneration is associated with the reversion of both myelinating and nonmyelinating SCs distal to the lesion to an immature phenotype (Aguayo et al., 1982; Fawcett and Keynes, 1990; Jessen and Mirsky, 1999) and with extensive SC proliferation that continues in response to axonal regrowth. The immature SCs provide a permissive substrate for regrowing axons, because of the secretion of growth factors, the production of extracellular matrix components such as laminin (Anton et al., 1994), and the reexpression of cell adhesion molecules such as L1 (Lemmon et al., 1989), entities that promote neurite outgrowth. A second pathological situation in which the immature Schwann cell population is expanded, however in the continual presence of axons, is the hereditary neuropathy Charcot-Marie-Tooth type 1A (CMT1A) in humans (Scherer, 1997; Hanemann and Müller, 1998).

We have described recently a $330 \mathrm{kDa}$ cell-surface glycoprotein of oligodendroglial progenitor cells termed AN2 (Niehaus et al., 1999). Initial results suggested additional expression by SCs. In this study we investigated the expression of AN2 in the PNS during normal development and pathological situations. We show that AN2 is expressed by immature, promyelinating, and a subpopulation of nonmyelinating SCs. Surprisingly, crushing the rat sciatic nerve did not result in a large change in the expression level of AN2. In contrast, peripheral myelin protein-22 (PMP22)-transgenic rats exhibit an increased expression of AN2. This study demonstrates that AN2 is a novel marker for the SC lineage. Furthermore, the analysis of these pathological situations, as well as in vitro experiments showing increased AN2 expression by immature SCs in coculture with neurons, suggests that AN2 expression may be regulated by axonal contact. Matrix-assisted 
laser desorption/ionization time-of-flight mass spectrometry (MALDI TOF mass spectrometry; abbreviated MALDI MS) analysis of purified AN2 from early postnatal mouse brain as well as Edman sequencing of peptides demonstrated that AN2 is the murine homolog of the rat NG2 proteoglycan.

\section{MATERIALS AND METHODS}

Materials. Polyvinylidene difluoride (PVDF) membrane was from Millipore (Bedford, MA). 2,2'-Azino-bis(3-ethylbenzthiazoline-6-sulfonic acid) (ABTS), dibutyryl cAMP (dbcAMP), cytosine arabinoside (AraC), laminin (LN), normal goat serum (NGS), poly-L-lysine (PLL), protease inhibitors (PMSF, aprotinin, pepstatin, amino- $n$-capronic acid, antipain, leupeptin, soybean trypsin inhibitor, and benzamidine), swainsonine, 3-aminopropyltriethoxysilan (TESPA), and tunicamycin were purchased from Sigma (Deisenhofen, Germany). $N$-octyl- $\beta$-D-glucoside (octylglucoside) and bovine serum albumin (BSA) fraction $\mathrm{V}$ were from AppliChem (Darmstadt, Germany), collagenase type 4 was from Worthington (Lakewood, NJ), NGF (human recombinant $\beta$-NGF) was from Tebu (Frankfurt am Main, Germany), chondroitinase ABC was from Boehringer Mannheim (Mannheim, Germany), and nitrocellulose BA85 was from Schleicher \& Schuell (Dassel, Germany).

Antibodies. The following antibodies were used: rat monoclonal antibody and rabbit polyclonal antibody against AN2 (Niehaus et al., 1999), mouse monoclonal antibody 513 against MAG (Poltorak et al., 1987), rabbit polyclonal antibody against S-100 (Dakopatts, Hamburg, Germany), rat monoclonal antibody 324 against L1 (Rathjen and Schachner, 1984), mouse monoclonal antibody 192 against 75 neurotrophin receptor (p75NTR), rabbit polyclonal antibody against p75NTR (Chemicon, Temecula, CA), rabbit polyclonal antibody against tenascin-C (a kind gift of Dr. A. Faissner), rabbit polyclonal antibody against laminin (a kind gift of Dr. A. Faissner), mouse monoclonal antibody against $\alpha$-tubulin (Sigma), and FITC-conjugated mouse monoclonal antibody against bromodeoxyuridine (BrdU; Becton Dickinson, Heidelberg, Germany). Secondary polyclonal antibodies were purchased from Dianova (Hamburg, Germany).

Animals and surgery. NMRI mice of both sexes were obtained from the central animal facilities of the University of Heidelberg. For crushes of sciatic nerve, adult Wistar rats (200-240 gm) obtained from the central animal facilities of the University of Düsseldorf were anesthetized with chloral hydrate $(350 \mathrm{mg} / \mathrm{kg}$ body weight $)$ administered intraperitoneally. Both sciatic nerves were crushed with jeweler's forceps, and the wounds were dressed. At distinct time points after lesion the injured sciatic nerves were removed, and a segment of 3-4 mm containing the site of injury was discarded. The resulting distal and proximal nerve fragments were frozen in liquid nitrogen before protein preparation or fixed by immersion in $4 \%$ paraformaldehyde (PFA) for immunofluorescence analysis. All animal experiments were performed according to the guidelines of the German animal rights law. The generation and genotype analysis of PMP-22-transgenic rats have been described (Sereda et al., 1996).

Cell culture. Dorsal root ganglion (DRG) explants, cultures of DRG neurons, primary SCs, and the Schwann cell clone SVK1 (Jung et al., 1994) were cultured in chemically defined medium [def. medium, according to Morgan et al. (1991), with modifications; a 1:1 mixture of DMEM and Ham's F12 containing $15 \mathrm{~mm}$ HEPES and supplemented with 160 $\mathrm{ng} / \mathrm{ml}$ selenium, $10 \mathrm{ng} / \mathrm{ml}$ tri-iodothyrodine, $100 \mu \mathrm{g} / \mathrm{ml}$ transferrin, 16 $\mu \mathrm{g} / \mathrm{ml}$ putrescine, $0.4 \mu \mathrm{g} / \mathrm{ml}$ thyroxine, $60 \mathrm{ng} / \mathrm{ml}$ progesterone, $0.3 \mathrm{mg} / \mathrm{ml}$ BSA, $5 \mu \mathrm{g} / \mathrm{ml}$ insulin, and $2 \mathrm{~mm}$ L-glutamine] with the addition of factors as indicated in the text. The oligodendroglial cell line Oli-neu (Jung et al., 1995) was cultured in Sato and 1\% horse serum (HS). All cells were cultured at $37^{\circ} \mathrm{C}$ and $5 \% \mathrm{CO}_{2}$ except for the Schwann cell clone SVK1 that was cultured at $33^{\circ} \mathrm{C}$ and $5 \% \mathrm{CO}_{2}$.

DRG explants for neurite outgrowth assays were prepared from postnatal day $0(\mathrm{P} 0)-\mathrm{P} 1$ mice, collected in ice-cold HBSS, incubated with 480 $\mathrm{mU} / \mathrm{ml}$ collagenase for $30 \mathrm{~min}$ at $37^{\circ} \mathrm{C}$, washed twice with ice-cold Eagle's Basal Medium (BME) containing 10\% fetal calf serum (FCS), and subsequently transferred to appropriately coated surfaces. The explants were cultured in chemically defined medium with addition of $1 \%$ HS, $0.05 \mathrm{~mm} \mathrm{AraC}$, and $50 \mathrm{ng} / \mathrm{ml} \mathrm{NGF}$. After $24 \mathrm{hr}$ they were fixed and processed for toluidine blue staining (Niehaus et al., 1999).

DRG explant cultures for examination of associated SCs by immunofluorescence staining were established as described for neurite outgrowth assays but cultured for $4 \mathrm{~d}$ on PLL-coated glass coverslips in chemically defined medium with the addition of $1 \% \mathrm{HS}$ and $20 \mathrm{ng} / \mathrm{ml}$ NGF.
Cultures of purified DRG neurons were established from P0-P1 mice according to the method of Seilheimer and Schachner (1988). The neurons were enriched by flotation on a 35\% Percoll gradient and subsequently plated on PLL- or laminin-coated coverslips in BME with $10 \% \mathrm{HS}$ and $200 \mathrm{ng} / \mathrm{ml} \mathrm{NGF}$. To eliminate the remaining non-neural cells, $0.025 \mathrm{~mm}$ AraC was added daily to the medium. After $5-7 \mathrm{~d}$ the medium was changed to chemically defined medium plus $100 \mathrm{ng} / \mathrm{ml}$ NGF, and $1 \mathrm{~d}$ later, purified SCs (see below) were added. The neuron-SC cocultures were processed for indirect immunofluorescence after 3-12 d.

DRG neuron-conditioned medium was obtained from cultures of purified DRG neurons that were established as described above. After 5-7 $\mathrm{d}$ the medium was changed to chemically defined medium plus $1 \% \mathrm{HS}$ and $200 \mathrm{ng} / \mathrm{ml} \mathrm{NGF}$. Conditioned medium was collected every second day and centrifuged $\left(10 \mathrm{~min} ; 132 \times g ; 4^{\circ} \mathrm{C}\right)$ before addition to purified Schwann cell cultures (see below). Control Schwann cells were cultured in the same medium without neuronal conditioning. The Schwann cell cultures were processed for indirect immunofluorescence after 3-9 d.

Primary cultures of SCs were established following the method of Brockes et al. (1979) with modifications. Sciatic nerves of P5-P7 mice were digested with $0.3 \%$ collagenase and $0.25 \%$ trypsin and dissociated by three cycles of trituration through a hypodermic needle (23 gauge) in the presence of $0.025 \%$ DNase and $10 \%$ FCS. The resulting cell suspension was plated on PLL-coated dishes in DMEM containing 10\% FCS and $2 \mathrm{mM}$ L-glutamine and treated with $0.01 \mathrm{~mm} \mathrm{AraC} \mathrm{for} 48 \mathrm{hr}$ to remove rapidly dividing fibroblasts. The enriched SCs (at least $95 \%$ pure) were plated onto cultures of purified DRG neurons, onto glass coverslips or dishes coated with PLL or LN, and cultured for further use in chemically defined medium with the addition of different factors as indicated in the text. Samples were examined with an Axiophot fluorescence microscope (Zeiss, Oberköchen, Germany).

Immunofluorescence. Staining of cultures for indirect immunofluorescence was performed as described by Schnitzer and Schachner (1981). SCs were identified by morphology and expression of the L1 and p75NTR proteins. Proliferation of primary SCs was determined by incorporation of BrdU. BrdU $(10 \mu \mathrm{M})$ was added to the medium 15-20 hr before staining. The cells were fixed and stained for expression of the AN2 antigen by the use of a Texas Red-conjugated secondary antibody. Cells were fixed again for 15 min with $4 \%$ PFA, washed with PBS, permeabilized for 20 min with $0.05 \%$ Tween 20 in $4 \mathrm{~N} \mathrm{HCl}$, and neutralized for 5 min with $0.1 \mathrm{M}$ Borax buffer. Subsequently, cells were washed with PBS, incubated for 30-60 min with the FITC-conjugated mouse monoclonal antibody against BrdU, washed with PBS, and mounted in Moviol (Hoechst, Frankfurt, Germany).

For staining of sciatic nerve sections, anesthetized P8 and adult mice were fixed by perfusion using a solution containing 2\% PFA, $0.01 \mathrm{M}$ sodium periodate, and $0.075 \mathrm{M} \mathrm{L}$-lysine in PBS (McLean and Nakane, 1974). Sciatic nerves were removed, postfixed for $3-5 \mathrm{hr}$ in the same fixative that was used for perfusion at $4^{\circ} \mathrm{C}$, cryoprotected in $20 \%$ sucrose overnight at $4^{\circ} \mathrm{C}$, and embedded in Jung Tissue Freezing Medium (Leica, Nussloch, Germany). Mouse embryos were fixed in 4\% PFA and $4 \%$ sucrose in PBS overnight at $4^{\circ} \mathrm{C}$, followed by $4-6 \mathrm{hr}$ of cryoprotection in $20 \%$ sucrose at $4^{\circ} \mathrm{C}$ and embedding. Unoperated and distal and proximal parts of crushed rat sciatic nerve were fixed in $4 \%$ PFA overnight at $4^{\circ} \mathrm{C}$, cryoprotected for $4-6 \mathrm{hr}$ in $20 \%$ sucrose at $4^{\circ} \mathrm{C}$, and embedded. Sciatic nerves of homozygous CMT1A rats and wild-type littermates were snap-frozen and embedded.

Eight micrometer cryosections were cut, collected on TESPA-coated slides, and allowed to dry. After fixation for $10 \mathrm{~min}$ in 4\% PFA, sections were washed in PBS, quenched in $0.1 \mathrm{M}$ glycine, $\mathrm{pH} 7.5$, for $10 \mathrm{~min}$, washed, blocked for $1 \mathrm{hr}$ with $10 \%$ NGS and $0.1 \%$ Triton X-100 in PBS, and incubated with primary antibody in blocking solution overnight at $4^{\circ} \mathrm{C}$. The sections were washed and incubated with secondary antibody (FITC-conjugated goat anti-rabbit, species-specific indocarbocyanineconjugated goat anti-rabbit or -rat, or species-specific Cy2-conjugated goat anti-mouse) for $1 \mathrm{hr}$ in blocking solution, washed, rinsed briefly in water, and mounted in Moviol. Nuclei were visualized by incubating the sections for $10 \mathrm{~min}$ in bisbenzimide $(0.05 \mathrm{mg} / \mathrm{ml})$ after the incubation with the secondary antibody. In some experiments an additional quenching step was inserted after the incubation with primary antibody. Sections were incubated for $10 \mathrm{~min}$ in a freshly prepared solution of $10 \mathrm{mg} / \mathrm{ml}$ $\mathrm{NaBH}_{4}$ in water. Samples were examined with a fluorescence microscope (Axiophot; Zeiss) and a confocal laser-scanning microscope (TCS 4D; Leica, Bensheim, Germany).

Electron microscopy. Anesthetized homozygous CMT1A rats were perfused with a solution containing 5\% glutaraldehyde and 4\% PFA in 
sodium cacodylate. Sciatic nerves were removed, postfixed overnight with $4 \%$ PFA in PBS, and cryoprotected in $2.1 \mathrm{M}$ sucrose in PBS. The frozen tissue was incubated for $55 \mathrm{hr}$ in methanol containing $1.5 \%$ uranyl acetate and subsequently embedded in methanol and Lowicryl. Ultrathin sections were treated with uranyl acetate and lead citrate. The sections were examined in an electron microscope (EM 10; Zeiss).

Isolation of the AN2 protein by affinity chromatography. AN2 protein was isolated from P9-P10 mouse brains as described by Niehaus et al. (1999).

Preparation of sciatic nerve lysates and enzymatic digestion of chondroitin sulfate residues. Samples of sciatic nerve for the developmental blot were ground in liquid nitrogen and homogenized with an UltraTurrax T25 (IKA-Labortechnik, Staufen, Germany) at low speed in ice-cold solubilization buffer [PBS and $60 \mathrm{~mm}$ octylglucoside containing protease inhibitors as described in Niehaus et al. (1999)], and the extracts were shaken for $1 \mathrm{hr}$ at $4^{\circ} \mathrm{C}$. Insoluble material was separated by centrif ugation $\left(3000 \times g ; 15 \mathrm{~min} ; 4^{\circ} \mathrm{C}\right)$; the protein content in the supernatant was determined with a Bio-Rad (Munich, Germany) protein assay.

Samples of nerve from the crush experiment were extracted the same way with ice-cold solubilization buffer containing $60 \mathrm{~mm}$ octylglucoside, $2 \mathrm{M}$ urea, and protease inhibitors in PBS. The insoluble material was separated by centrifugation and reextracted. The supernatants of the two extractions were combined, and the protein content was determined as described above. To ensure complete extraction of the antigens from samples of crushed nerve, the pellets of the octylglycoside and urea lysates were boiled in $8 \mathrm{M}$ urea, $5 \%$ SDS, and $1 \% \beta$-mercaptoethanol. No additional AN2 protein could be detected in these final lysates by Western blot analysis (data not shown). This indicates that the AN2 protein was completely extracted with the first buffer and that no insoluble fraction of the protein remained in the pellet.

Sciatic nerve extracts from PMP-22-transgenic and wild-type rats were prepared according to the method of Sereda et al. (1996).

Gel electrophoresis and immunoblotting. SDS-PAGE was performed according to the method of Laemmli (1970) by using $4-10 \%$ gradient gels. Proteins were blotted on a PVDF membrane by semidry transfer. HRP-conjugated secondary antibodies were used, and bound antibodies were detected by the ECL method (Amersham-Buchler, Braunschweig, Germany).

Biochemical studies on the AN2 protein in the PNS. For steady-state radiolabeling of primary SCs cultured for $3 \mathrm{~d}$ in chemically defined medium with $10 \%$ FCS, the cell line Oli-neu, and the Schwann cell clone SVK1, cells were starved for $1 \mathrm{hr}$ in methionine- and cysteine-free DMEM with $2 \mathrm{mM}$ L-glutamine. The cells were then labeled for $4 \mathrm{hr}$ with $100 \mu \mathrm{Ci} / \mathrm{ml} \mathrm{L}-\left({ }^{35} \mathrm{~S}\right)$ in vitro-labeling mix consisting of $70 \%$ methionine and $30 \%$ cysteine (Amersham-Buchler). The AN2 protein was immunoprecipitated both from cell lysates and supernatant according to the method of Niehaus et al. (1999), by use of the monoclonal AN2 antibody and protein G-Sepharose (Pharmacia) that had been preincubated with rabbit anti-rat "bridge" antibody.

Substrate preparation for neurite outgrowth assays. Substrates for neurite outgrowth assays were prepared on nitrocellulose or on PLL. Petri dishes $(35 \mathrm{~mm})$ were coated with $0.01 \%$ PLL for at least $1 \mathrm{hr}$ at $37^{\circ} \mathrm{C}$, washed with PBS twice, and incubated with PBS, AN2 $(40 \mu \mathrm{g} / \mathrm{ml}), \mathrm{LN}(5 \mu \mathrm{g} / \mathrm{ml})$, or a mixture of $\mathrm{AN} 2$ and $\mathrm{LN}$ (at the same concentration used for the single components) for $1-2 \mathrm{hr}$ at $4^{\circ} \mathrm{C}$. Alternatively, $600 \mu \mathrm{l}$ of nitrocellulose dissolved in methanol $\left[1 \mathrm{~cm}^{2}\right.$ of nitrocellulose in $2.4 \mathrm{ml}$ of methanol (Lagenaur and Lemmon, 1987)] was spread over the surface of a Petri dish $(35 \mathrm{~mm})$ and air dried. Protein samples with the same concentrations as above were incubated on this substrate for $10 \mathrm{~min}$ at room temperature and washed, and the coated surface was subsequently blocked with def. medium containing $1 \% \mathrm{HS}$ and $1 \mathrm{mg} / \mathrm{ml} \mathrm{BSA} \mathrm{(45} \mathrm{min}$ at $58^{\circ} \mathrm{C}$, heat inactivated) for $1-2 \mathrm{hr}$ at $37^{\circ} \mathrm{C}$. In each case DRG explants were added to the washed substrate. The AN2 protein prepared from P9-P10 mouse brains was used for all functional assays.

The optimal protein concentration for efficient substrate coating on both PLL and nitrocellulose for neurite outgrowth assays was determined by ELISA. After substrate coating as described above and washing, the dishes were blocked with PBS containing $0.05 \%$ Tween 20 and $4 \%$ milk powder, incubated for $1.5 \mathrm{hr}$ at $37^{\circ} \mathrm{C}$ with primary antibody diluted in $0.05 \%$ Tween 20 in PBS, washed with $0.05 \%$ Tween 20 in PBS, incubated for $1.5 \mathrm{hr}$ at $37^{\circ} \mathrm{C}$ with HRP-coupled secondary antibody diluted in $0.05 \%$ Tween 20 in PBS, washed in $0.05 \%$ Tween 20 in PBS, and incubated with ABTS substrate solution in the dark until sufficient color developed. The reaction was stopped by addition of $0.6 \%$ SDS, and the extinction was measured at $405 \mathrm{~nm}$.
Quantitation of neurite length. Neurite length was measured using the Leica (Bensheim, Germany) Quantimate 500 software in combination with an inverted microscope and an attached camera. Because neurites growing out from the DRG explant fasciculate strongly, the area covered by the neurite halo rather than the length of single neurites was determined. The area covered by the body of the DRG and the area covered by the neurite halo and the body of the DRG were measured. The area of outgrowing neurites was determined by subtraction of these two areas. For each substrate, 15 DRGs were explanted, and 5-15 DRGs were measured for one data point. Because it cannot be assumed that neurite outgrowth follows a Gaussian distribution, the nonparametric test ANOVA on ranks followed by Dunn's test was applied to analyze the results.

Migration assay. An in vitro migration assay using the immortalized Schwann cell clone SVK1 was established according to the methods of Niehaus et al. (1999) and Amberger et al. (1997). Aggregate cultures of SV K1 were generated by suspending the cells at $0.6 \times 10^{6} \mathrm{cells} / \mathrm{ml}$ in def. medium containing $1 \% \mathrm{HS}$ in glass flasks rotating at $70 \mathrm{rpm}$ and $33^{\circ} \mathrm{C}$. After $16 \mathrm{hr}$, the aggregates were plated on coverslips coated with PLL in culture medium containing $400 \mu \mathrm{g} / \mathrm{ml}$ polyclonal AN2 antibodies (Niehaus et al., 1999) or the same volume of PBS. The migration velocity and the distance migrated were analyzed by videomicroscopy. After an initial attachment phase of $7 \mathrm{hr}$, the migration of cells out of the aggregates was filmed for $11 \mathrm{hr}$ at $33^{\circ} \mathrm{C}$ using an inverted microscope (Leitz, DM IRB; Leica, Bensheim, Germany) with an attached digital camera (Quantics; Photometrics) and using the software IPLab 3.2.2 (Scananalytics, Inc.). Pictures were taken every hour, and the migration velocity and distance migrated were determined for each individual cell of several aggregates. Three independent experiments, each including measurements of at least 20 cells, were pooled for each experimental condition (plus polyclonal AN2 antibodies or PBS). The nonparametric test ANOVA on ranks followed by Dunn's test was applied to analyze the results because it cannot be assumed that migration follows a Gaussian distribution.

Enzymatic digestion of immunoaffinity-purified AN2 for MALDI MS analysis. Immunoaffinity-purified AN2 protein $(110 \mu \mathrm{g})$ from P9-P10 mouse brain was incubated with $100 \mathrm{mU}$ of chrondroitinase $\mathrm{ABC}$ for $5 \mathrm{hr}$ at $37^{\circ} \mathrm{C}$. The sample was precipitated with acetone, taken up in sample buffer, and subjected to SDS gel electrophoresis (4-10\% gradient gel; 1 $\mathrm{mm}$ thick). The Coomassie-stained AN2 protein band was excised from the gel and cut into small pieces $(\sim 1 \times 1 \mathrm{~mm})$. The gel pieces were washed twice with water and $50 \%$ acetonitrile in water and finally shrunk with acetonitrile. The protein was digested in the gel with trypsin (sequencing grade modified porcine trypsin from Promega, Madison, $\mathrm{WI}$ ) in $40 \mathrm{~mm}$ ammonium bicarbonate overnight at $37^{\circ} \mathrm{C}$. The reaction was stopped by freezing.

MALDI mass spectrometry. MALDI mass spectra were recorded in the positive ion mode with delayed extraction on a Reflex II time-of-flight instrument (Bruker-Daltonik GmbH, Bremen, Germany) equipped with a SCOUT multiprobe inlet and a $337 \mathrm{~nm}$ nitrogen laser. Ion acceleration voltage was set to $20.0 \mathrm{kV}$, the reflector voltage was set to $21.5 \mathrm{kV}$, and the first extraction plate was set to $15.7 \mathrm{kV}$. The mass spectrum was obtained by averaging 140 individual laser shots. Calibration of the spectrum was performed internally with two autolysis products of trypsin at $\mathrm{m} / \mathrm{z} 842.50$ and $\mathrm{m} / \mathrm{z} 2211.10$.

Sample preparation was achieved by use of the thin-film preparation techniques (Jensen et al., 1996). Briefly, $0.3 \mu$ l aliquots of a nitrocellulose containing a saturated solution of $\alpha$-cyano-4-hydroxycinnamic acid (Sigma-Aldrich, Deisenhofen, Germany) in acetone were deposited onto individual spots on the target. Subsequently, $0.8 \mu \mathrm{l}$ of $10 \%$ formic acid and $0.4 \mu \mathrm{l}$ of the digest sample were loaded on top of the thin-film spots and allowed to dry slowly at ambient temperature. To remove salts from the digestion buffer, the spots were washed with $10 \%$ formic acid and with $\mathrm{H}_{2} \mathrm{O}$.

Reversed-phase chromatography. The gel containing the tryptic fragments was extracted twice with $0.1 \%$ trifluoroacetic acid (TFA) and $60 \%$ acetonitrile. The extracted fragments were separated on a capillary HPLC system equipped with a 140B solvent delivery system (Applied Biosystems), Accurate splitter (LC-Packings), UV absorbance detector 759A (Applied Biosystems), UZ capillary flow cell (LC-Packings), and Probot fraction collector (BAI) using a reversed-phase column (Hypersil C18 BDS $3 \mu \mathrm{m} ; 0.3 \times 150 \mathrm{~mm})$ and a linear gradient from $12 \%$ acetonitrile and $0.1 \%$ TFA in water to $64 \%$ acetonitrile and $0.08 \%$ TFA in $90 \mathrm{~min}$ with a flow rate of $4 \mu \mathrm{l} / \mathrm{min}$ at room temperature. Peptide elution was monitored at $214 \mathrm{~nm}$, and individual fractions from the HPLC separation were analyzed by MALDI mass spectrometry. 
$\mathbf{A}$
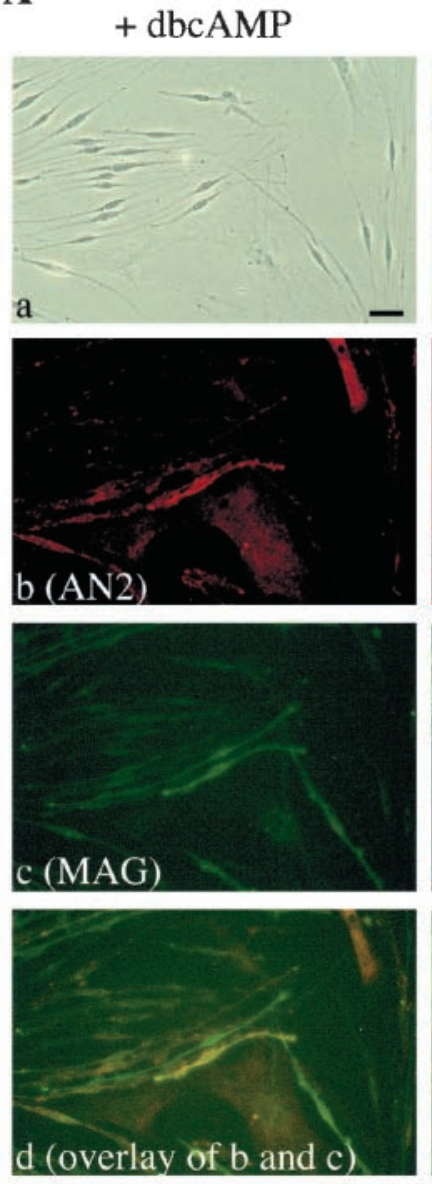

B

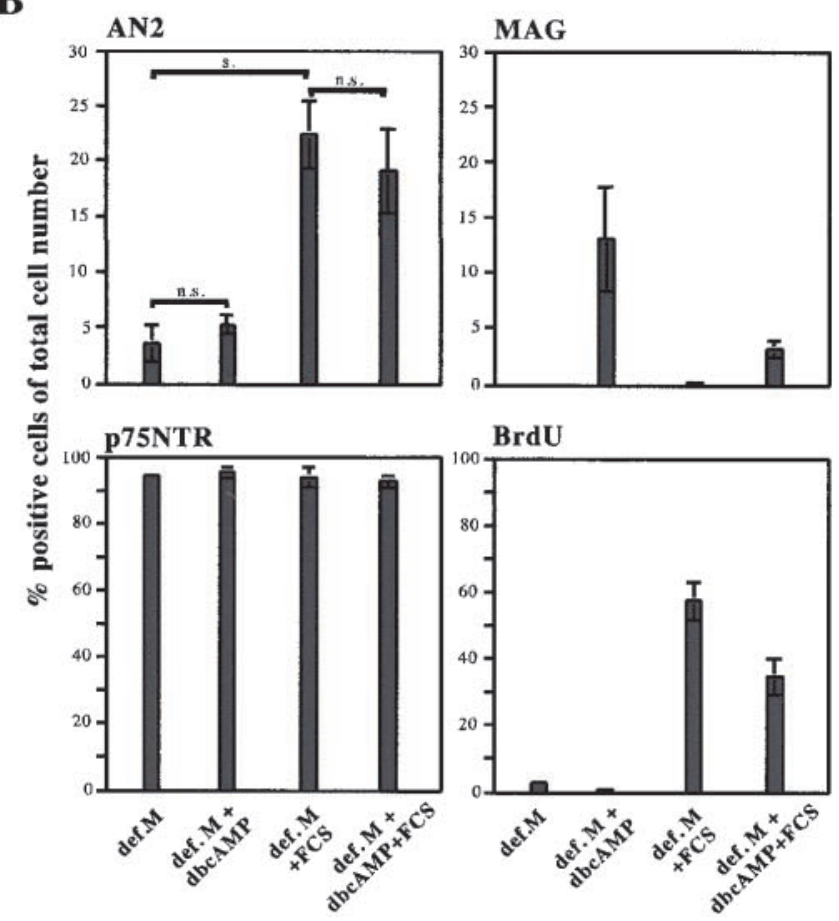

Figure 1. The expression of the AN2 protein by Schwann cells is upregulated by serum factors. $A$, Primary SCs were cultured for $2 \mathrm{~d}$ in chemically defined medium with addition of $1 \mathrm{~mm}$ dbcAMP $(a-d)$ or $10 \%$ FCS $(e-h)$ and subsequently stained with AN2 polyclonal $(b)$ and monoclonal $(f)$ antibodies, MAG monoclonal antibodies $(c)$, and p75NTR
Edman sequencing. Sequence analysis of fragments was performed on a Procise Protein Sequencer 494cLC (Applied Biosystems) using standard programs supplied by the manufacturer.

Database search. A database search was performed with the peptide masses against the nonredundant database of the National Center for Biotechnology Information by use of the search program ProFound (http://129.85.19.192/prowl-cgi/ProFound.exe) provided by the Rockefeller University (New York, NY). Mass tolerance for the monoisotopic peptide masses was set to $0.1 \mathrm{Da}$. The FastA database-searching program of Lipman and Pearson (1985) was used for sequence identification in databases.

\section{RESULTS}

\section{In vitro immature Schwann cells express the AN2 protein, and the expression is enhanced by coculture with neurons}

The AN2 protein was expressed by primary murine SCs judged by the overlap of AN2 expression with markers for immature SCs such as p75NTR (Fig. 1A,e-h). Expression of AN2 by a few contaminating cells of fibroblast morphology was additionally observed (Fig. 1A,h). SCs express low levels of the AN2 protein when cultured in chemically defined medium (Fig. 1B). The addition of dbcAMP, which promotes the differentiation of SCs toward a myelinating phenotype that is evidenced by expression of MAG (Fig. 1A,c,B), did not significantly alter the expression of AN2 (Fig. 1B). Approximately one-quarter of the AN2-positive cells were also double-labeled with MAG (Fig. $1 A, a-d$ ). In contrast, SC expression of AN2 was upregulated by serum, which additionally stimulates proliferation of immature SCs (Fig. 1). The upregulation of AN2 was not, however, caused by selective proliferation of AN2-positive cells; compared with FCS alone the AN2 expression did not decrease significantly after simultaneous application of FCS and dbcAMP in spite of a reduction in BrdU incorporation of $>30 \%$ (Fig. $1 \mathrm{~B}$ ). Approximately one-quarter of the proliferating cells as well as one-quarter of the total number of cells were AN2 positive (data not shown).

An increased expression of AN2 by SCs was observed in cocultures of purified SCs with DRG neurons (Fig. 2A). In the absence of neurons, purified SC cultures in chemically defined medium with or without addition of $1 \%$ HS contain $<5 \%$ AN2positive SCs (Fig. 1B). In contrast, in coculture with DRG neurons, $24 \pm 8 \%$ of all SCs in the culture were AN2 positive, and $32 \pm 5 \%$ of neurite-attached SCs expressed AN2. Almost $90 \%$ of all AN2-positive cells were associated with neurites and extended processes along them. Electron microscopic analysis and immunofluorescence staining for myelin proteins demonstrated that the SCs in these cocultures were at an immature stage of the

polyclonal antibodies $(g) . d$ shows the overlay of $b$ and $c$, and $h$ shows the overlay of $f$ and $g$. $a$ and $e$ show the corresponding phase-contrast pictures. Scale bars: $a-d, e-h, 25 \mu \mathrm{m}$. B, Primary SCs were grown for $2 \mathrm{~d}$ in chemically defined medium without addition of factors (def. $M$ ) or with addition of 1 mM dbcAMP (def. $M+d b c A M P$ ), $10 \%$ FCS (def. $M+F C S)$, or $1 \mathrm{mM}$ dbcAMP $+10 \%$ FCS (def. $M+d b c A M P+F C S)$ and subsequently stained with antibodies against AN2, p75NTR, and MAG and with $\alpha$-BrdU-FITC. Total cell numbers and the number of antigenpositive cells were determined by cell counting. Cells were judged to be antigen-positive if cell-surface staining was visible (in the case of AN2, MAG, and p75NTR) compared with negative control cells incubated with secondary antibodies alone. For each data point three identical coverslips were analyzed, and at least 300 cells in at least three different areas on one coverslip were counted. Mean values and SD were calculated, and statistical analysis was performed by use of the nonparametric Student-Newman-Keuls test (s., significantly different, $p<0.05 ; n$.s., not significantly different). One of three independent experiments yielding similar results is shown. 


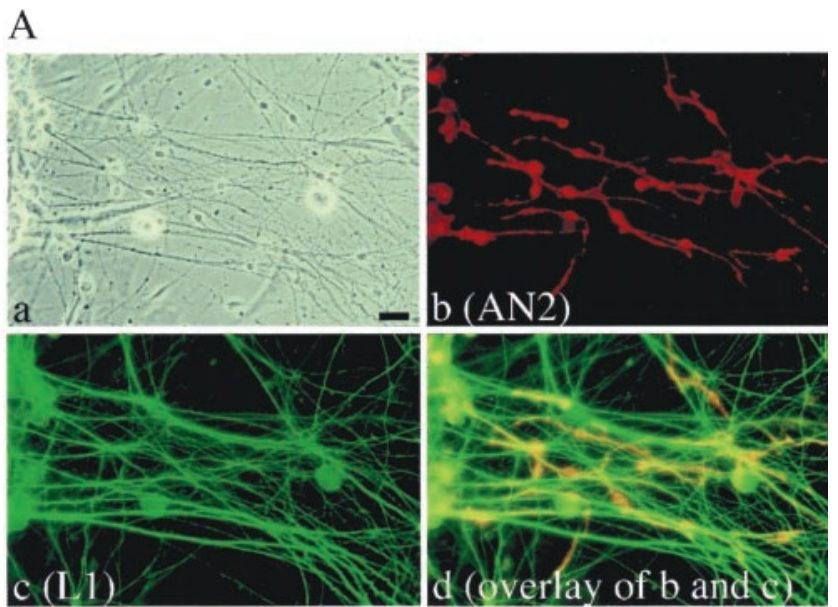

B


Figure 2. The expression of the AN2 protein by Schwann cells is upregulated in coculture with $\mathrm{DRG}$ neurons. $A, \mathrm{DRG}$ neurons from $\mathrm{P} 0$ mice were cultured for $5 \mathrm{~d}$ in BME with $10 \% \mathrm{HS}, 200 \mathrm{ng} / \mathrm{ml} \mathrm{NGF}$, and $50 \mathrm{~mm}$ AraC. Purified primary SCs were then added, and culturing continued for $12 \mathrm{~d}$ in def. medium with $1 \% \mathrm{HS}$ and $200 \mathrm{ng} / \mathrm{ml} \mathrm{NGF}$. The cocultures were stained with AN2 polyclonal antibodies $(b)$ and L1 monoclonal antibodies lineage and had not yet synthesized myelin (data not shown). Similarly, immunofluorescence staining of DRG explants cultured for $4 \mathrm{~d}$ in chemically defined medium with $1 \%$ serum demonstrated that SCs that attached to outgrowing neurites almost all expressed high amounts of AN2 (Fig. 2B, $a-e$ ), whereas the expression of AN2 by SCs in areas of the explants with few outgrowing neurites was much lower (Fig. $2 B, f-j$ ). In contrast to the cocultures, conditioned medium from DRG neurons had no effect on the expression of AN2 by SCs in neuron-free cultures (data not shown; see Materials and Methods for details) although SC proliferation was markedly increased. Together these results suggest the existence of a soluble axonal factor that is operative over a short distance or an axon-bound factor that upregulates the expression of AN2 by SCs.

\section{In vivo the AN2 protein is expressed by immature, promyelinating, and nonmyelinating Schwann cells}

In cryosections of P8 and adult mouse sciatic nerve, the AN2 antibodies stained long thin cells lying between myelinated axons. The staining for AN2 partially colocalized with that for p75NTR (Fig. $3 a-d$ ) and L1 (Fig. $3 e-h$ ), proteins expressed by immature and nonmyelinating SCs. At P0 and P4 (data not shown) as well as at P8 (Fig. 3b), the staining for AN2 was much more abundant than in the adult (Fig. $3 f$ ). Furthermore, some capillaries and cells of the perineurium were AN2 positive both in developing and adult sciatic nerve (Fig. $3 f$, arrow). No overlap was observed between AN2 staining and the paranodal and periaxonal expression of MAG in adult rat sciatic nerve (Fig. $3 i-l$ ). Together with the results of the in vitro analysis, these data suggest that the AN2 protein is expressed by immature SCs during development and by a subpopulation of nonmyelinating SCs in the adult.

\section{The expression and posttranslational modifications of the AN2 protein are developmentally regulated in the PNS}

The expression and posttranslational modification of the AN2 protein were investigated by Western blot analysis (Fig. 4A, a,b). As in the CNS (Niehaus et al., 1999), the AN2 monoclonal antibody specifically recognizes a protein of $330 \mathrm{kDa}$. The expression of the AN2 protein peaks between P4 and P12 and then decreases to a lower but still significant level in the adult. The decreased expression of AN2 in the adult was also confirmed by immunohistochemical analysis (Fig. $3 a-h$ ). Interestingly, a subfraction of the protein carried glucosaminoglycan side chains during early postnatal stages of PNS development. These could be removed by chondroitinase ABC digestion as shown in Figure $4 B$ for lysates of P8 mouse sciatic nerve. Depending on the length of blot exposure, several additional bands of lower molecular weight appeared, some of which increased in intensity after ChABC digestion.

\section{Biochemical characterization of the AN2 protein in the PNS}

Biosynthetic radiolabeling and immunoprecipitation from cell lysates of primary SCs, of the immortalized Schwann cell clone

(c). $d$ shows the overlay of $b$ and $c$, and $a$ shows the corresponding phase-contrast picture. $B$, DRG explants from $\mathrm{P} 0$ mice were cultured for $4 \mathrm{~d}$ in def. medium with $1 \% \mathrm{HS}$ and $50 \mathrm{ng} / \mathrm{ml} \mathrm{NGF}$ on PLL-coated coverslips and stained with AN2 polyclonal antibodies $(c, h$; the same exposure time) and $\mathrm{L}$ monoclonal antibodies $(d, i)$. Nuclei were visualized with bisbenzimide $(b, g)$. $e$ shows the overlay of $c$ and $d$, and $j$ shows the overlay of $h$ and $i . a$ and $f$ show the corresponding phase-contrast pictures. $a-d$ is a neurite-rich area; $f-j$ is a neurite-poor area. Scale bars: $A, B, 25 \mu \mathrm{m}$. 


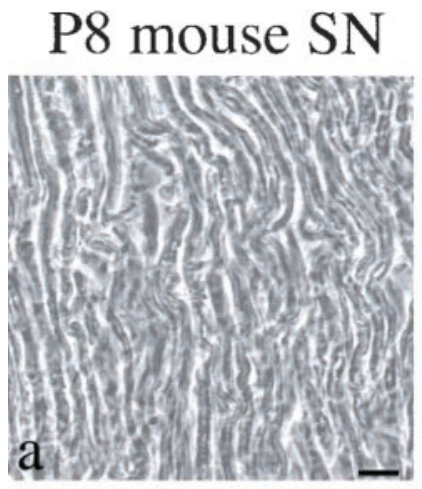

\section{adult mouse SN}
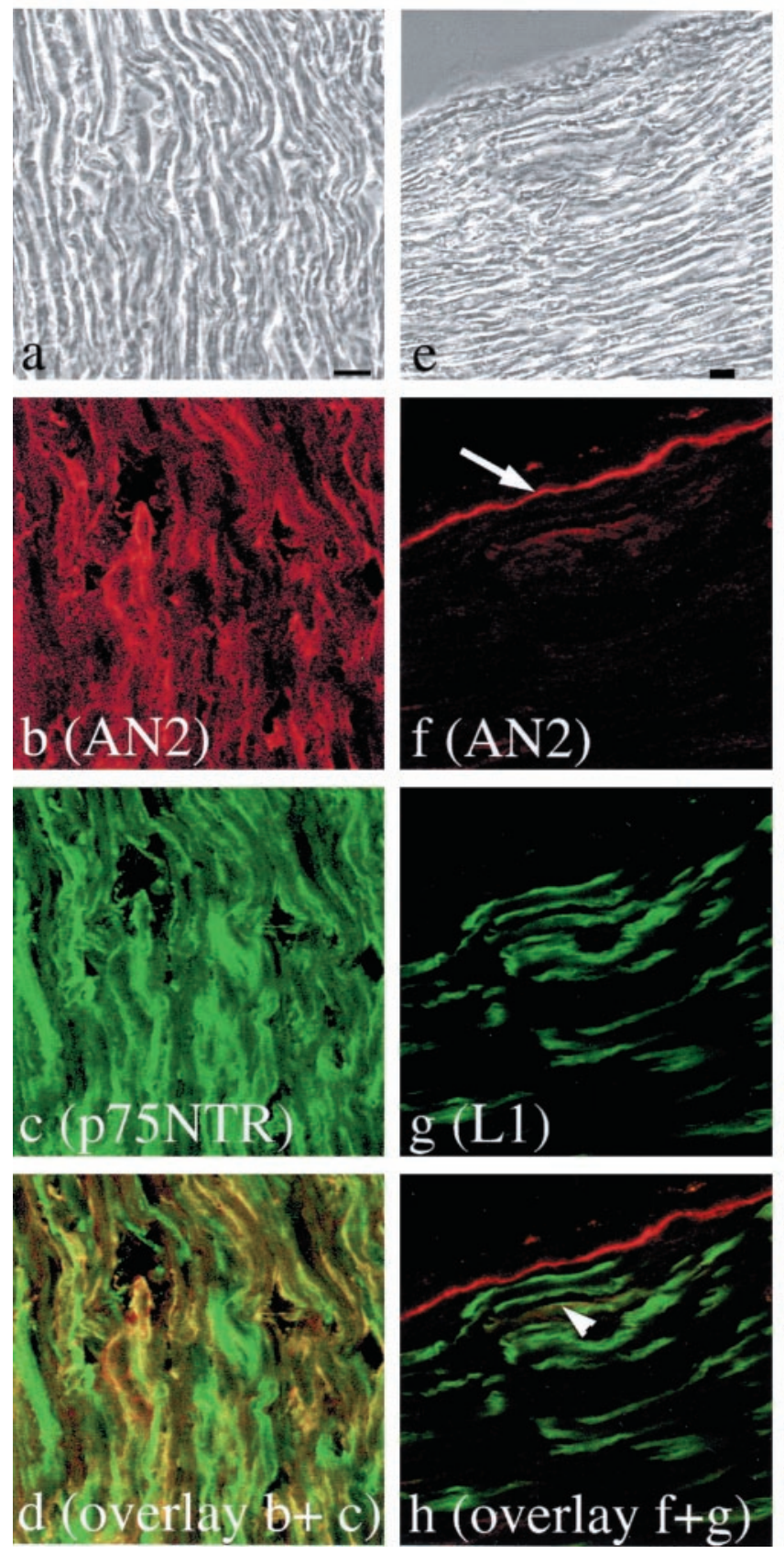

SVK1, and of the oligodendroglial cell line Oli-neu were performed to demonstrate synthesis of AN2 by SC and to characterize AN2 in the PNS in comparison with the CNS protein. Figure 5 shows that from both CNS and PNS cells the AN2 monoclonal antibody recognizes a protein of $330 \mathrm{kDa}$ that is the mature form of AN2, as well as a smear of higher molecular weight and a protein of $315 \mathrm{kDa}$ that is probably a precursor of the AN2 protein. Several weak bands were visible in the precipitates of cell lysates in the range of $100-300 \mathrm{kDa}$ that are specific for the monoclonal AN2 antibody. No signal for AN2 was detected in the culture supernatants of any of the cell lines tested.

\section{Expression of AN2 during Wallerian degeneration and subsequent regeneration}

We examined whether the expression of the AN2 protein is altered in the distal nerve stump after a peripheral nerve lesion

\section{adult rat $\mathrm{SN}$}
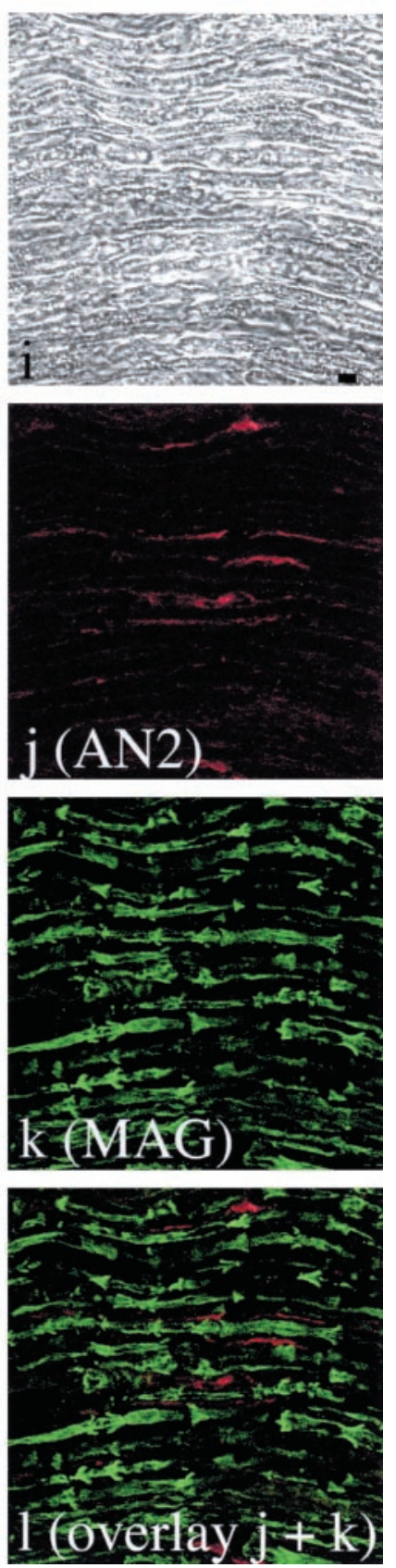

Figure 3. The AN2 protein is expressed by immature and nonmyelinating Schwann cells in vivo. Left, Middle, Longitudinal cryosections of P8 $(a-d)$ and adult $(e-h)$ mouse sciatic nerve $(S N)$ were stained with AN2 monoclonal $(b)$ and polyclonal $(f)$ antibodies, p75NTR polyclonal antibodies $(c)$, and L1 monoclonal antibodies $(g) . a$ and $e$ are the corresponding phase-contrast pictures. $d$ shows the overlay of $b$ and $c$, and $h$ shows the overlay of $f$ and $g$. The arrowhead in $h$ indicates an AN2 and L1 doublelabeled Schwann cell, and the arrow in $f$ points to AN2-positive cells of the perineurium. Right, A longitudinal section of adult rat $S N(i-l)$ was stained with AN2 polyclonal antibodies $(j)$ and MAG monoclonal antibodies $(k)$. $i$ shows the corresponding phase-contrast picture, and $l$ shows the overlay of $j$ and $k$. Single optical sections were analyzed by use of a confocal microscope. Scale bars: $a-d, e-h, i-l, 10 \mu \mathrm{m}$.

when the SC population expands after axonal degeneration and the antigenic phenotype reverts toward an immature pattern. Tissue was taken from distal and proximal stumps of rat sciatic nerve at 1 and 3 weeks after nerve crush as well as from sciatic nerves from unoperated littermates. No major difference in the expression of the AN2 protein in distal and proximal parts of crushed versus unoperated control sciatic nerves was observed in Western blots (Fig. 6A). A slight increase in the signal for AN2 in the proximal part of the nerve 3 weeks after the crush was observed, but compared with the changes in tenascin-C (see below), these changes were minor. The blots were stripped and reanalyzed for the expression of $\alpha$-tubulin to confirm that equal amounts of protein had been loaded in each lane. The expression of tenascin-C was heavily upregulated 1 week after the crush in the distal nerve stump and decreased to near 
A

a

Figure 4. Expression of the AN2 protein during postnatal development of the PNS. $A$, Octylglucoside $(60 \mathrm{~mm})$ lysates (each containing $50 \mu \mathrm{g}$ of protein) from mouse sciatic nerves of different developmental stages were subjected to electrophoretic separation and Western blotting. $a$, The blot was then incubated with AN2 monoclonal antibodies and developed with the ECL system (Amersham-Buchler). $b$, The membrane was stained with Poinceau S before antibody incubation, and the albumin band at $66 \mathrm{kDa}$ is shown to verify that equal amounts of protein were loaded per lane. $B, a$, Forty micrograms of total protein from P8 mouse sciatic nerve lysate as described in $A a$ were incubated with $(+)$ or without $(-) 10 \mathrm{mU}$ of chondroitinase $\mathrm{ABC}(\mathrm{Ch} A B C)$ for $5 \mathrm{hr}$ at $37^{\circ} \mathrm{C}$ before gel electrophoresis and Western blotting with AN2 polyclonal antibodies. $b$, The blot was reprobed with $\alpha$-tubulin antibodies to confirm that equal amounts of protein had been loaded in each lane. ad., Adult. Molecular weight markers are shown on the left.

b
A
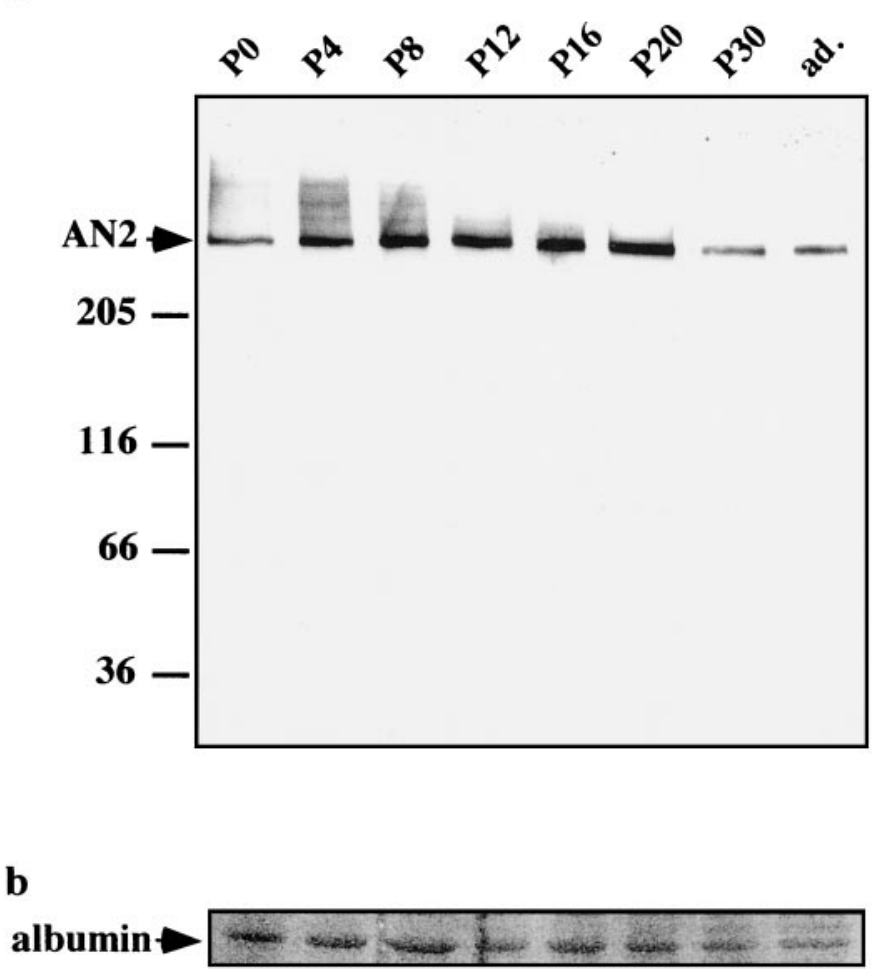

B

$\mathbf{a}$

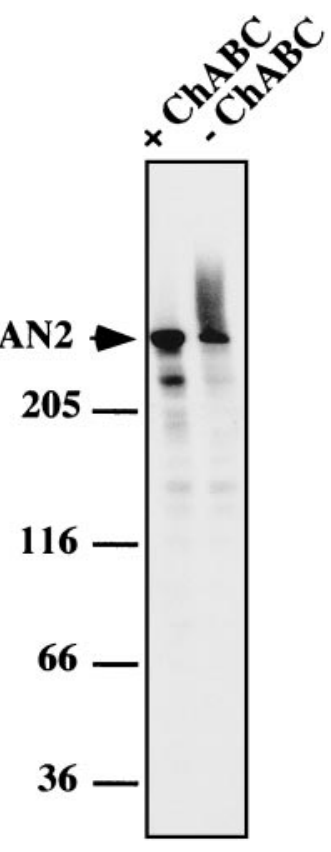

b

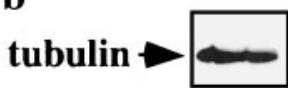

control levels 3 weeks after the crush as published previously (Martini et al., 1990), thus confirming the success of the experimental technique. On cryosections of distal, proximal, and unoperated sciatic nerves, no major differences in the expression of the AN2 protein could be detected at any time point analyzed. The staining for AN2 was evenly distributed throughout the distal nerve stumps 1 week (Fig. $6 B, b, C, b)$ and 3 weeks (Fig. 6B,e,C,e) after the crush. As expected, MAG could not be detected 1 week after the crush (Fig. 6C,c) and was reexpressed 2 weeks later (Fig. 6C,f). Although p75NTR and $\mathrm{MAG}$ are reciprocally expressed during development and regeneration, there is a small time window when they are coexpressed on SCs at the promyelinating stage (Zorick and Lemke, 1996). Thus, in nerve crushes, where the immature SC population expands after axonal degeneration and regrowth, no significant increase in AN2 expression was observed.

\section{Effect of AN2 on neurite outgrowth}

During nerve regrowth after a crush, neurites traverse an environment containing AN2-positive cells. We thus analyzed the response of DRG neurons to culture on AN2 or a mixture of AN2 and laminin substrates. The efficiency of coating of single and mixed substrates was determined by ELISA (Fig. $7 A)$. AN2 protein coated on PLL was a very poor substrate for neurite outgrowth (Fig. $7 B, C$ ) but did not reduce the ability of $\mathrm{LN}$ to promote the outgrowth of DRG neurites (Fig. $7 C$ ) in mixtures of AN2 and LN. With PLL as a basal substrate, there was no significant difference in the attachment of DRGs to the different substrates. On nitrocellulose, DRGs hardly attached to uncoated or AN2-coated surfaces, but they attached well to LN or LN and AN2 mixtures (data not shown). Thus although

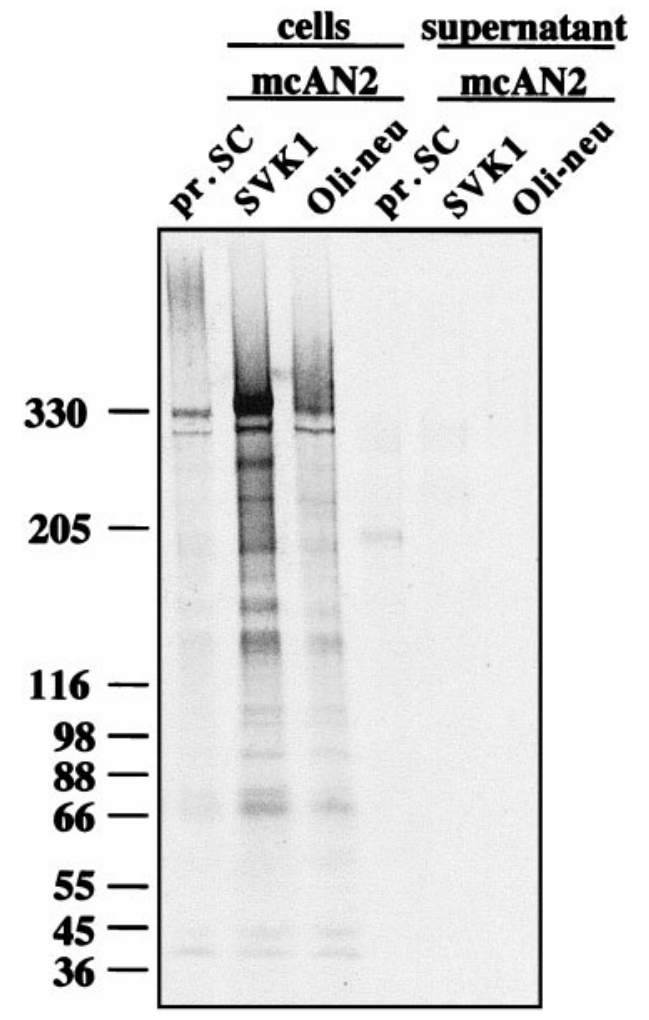

Figure 5. Synthesis and posttranslational modification of the AN2 protein in primary Schwann cells and the Schwann cell clone SVK1 compared with that of the oligodendroglial cell line Oli-neu. Immunoprecipitation with monoclonal AN2 antibodies $(m c A N 2)$ from cell lysates and supernatants of primary SCs ( $p r . S C)$, the SC clone SVK1, and the oligodendroglial cell line Oli-neu after radiolabeling is shown. 
A

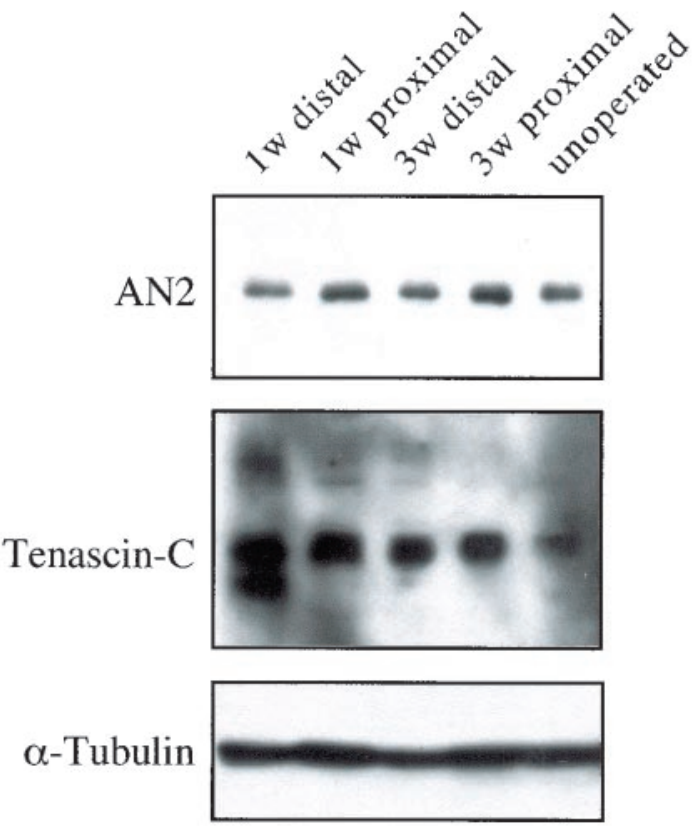

Figure 6. The expression level of the AN2 protein is not changed after sciatic nerve crush. $A$, Lysates of different sciatic nerve probes from operated and unoperated rats were separated by gel electrophoresis, blotted, and incubated with polyclonal antibodies against AN2. After stripping, the same blot was incubated with polyclonal antibodies against $\alpha$-tubulin and polyclonal antibodies against tenascin-C. Equal amounts of protein $(50 \mu \mathrm{g})$ were loaded per lane. $B$, Longitudinal cryosections of distal nerve stumps 1 week $(a-c)$ and 3 weeks $(d-f)$ after nerve crush and from unoperated littermates $(g-i)$ were stained with AN2 polyclonal antibodies $(b, e, h)$ and p75NTR monoclonal antibodies $(c$, $f, i$ ). Single optical sections were analyzed by use of a confocal microscope. $C$, Longitudinal cryosections of distal nerve stumps 1 week $(a-c)$ and 3 weeks $(d-f)$ after nerve crush and from unoperated littermates $(g-i)$ were stained with AN2 polyclonal antibodies $(b, e, h)$ and MAG monoclonal antibodies $(c, f, i)$. Single optical sections were analyzed by use of a confocal microscope. $a, b$, and $d$ in $B$ and $C$ show the corresponding phase-contrast pictures. Scale bars: $B, C, a-c, d-f, g-i, 10 \mu \mathrm{m}$. $w$, Week.

B

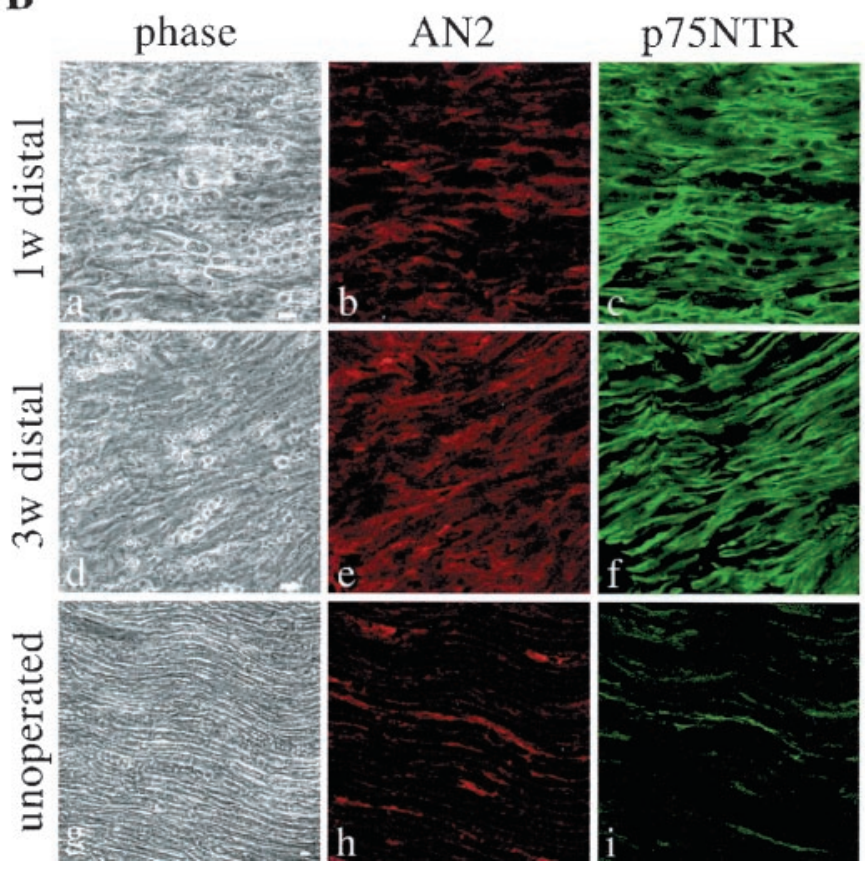

not supporting neurite attachment and growth, AN2 does not repulse neurites and does not override the highly supportive properties of laminin for growing neurites.

\section{The AN2 protein is involved in the migration of the Schwann cell clone SVK1}

The AN2 protein is expressed during several stages of the Schwann cell lineage, many of which are highly migratory. Furthermore, we have shown previously that AN2 plays a role in the migration of oligodendrocyte precursor cells (Niehaus et al.,
C

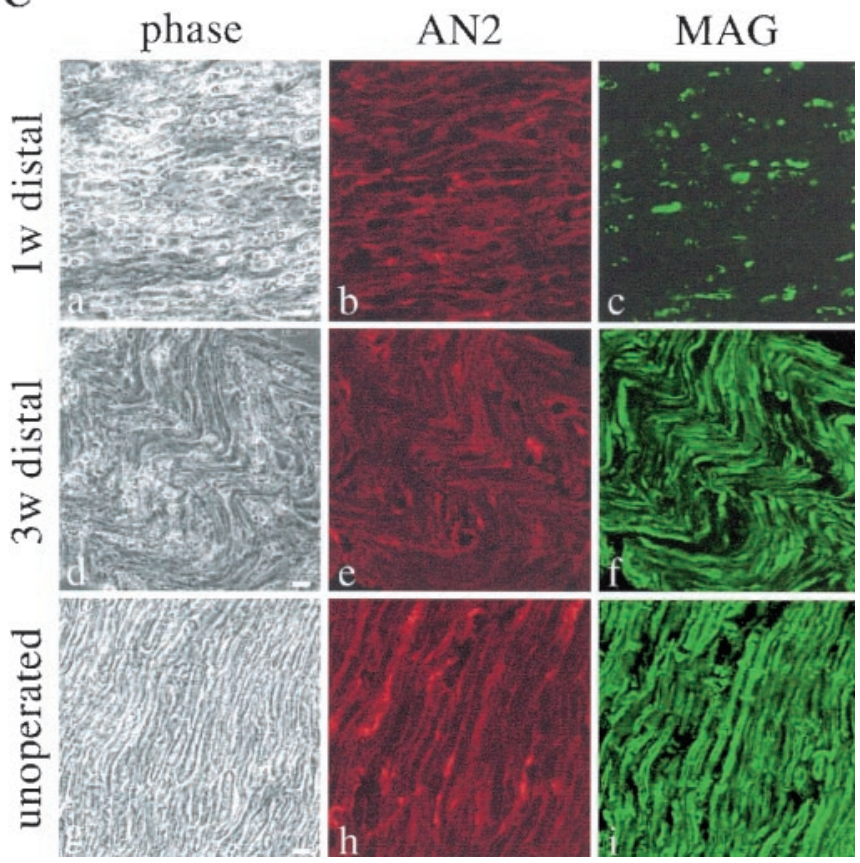

1999). To analyze a possible function of the AN2 protein in the migration of Schwann cells, we measured the migration distance and velocity of cells migrating from aggregates of the Schwann cell clone SVK1 by videomicroscopy. All cells of the SVK1 are AN2 positive (data not shown), and the biosynthesis of AN2 by this cell clone has been demonstrated (Fig. 5). The migration assay was performed in the presence or absence of $400 \mu \mathrm{g} / \mathrm{ml}$ polyclonal IgG AN2 antibodies, a concentration that has been shown to be maximally effective in inhibiting migration of oligo- 
A
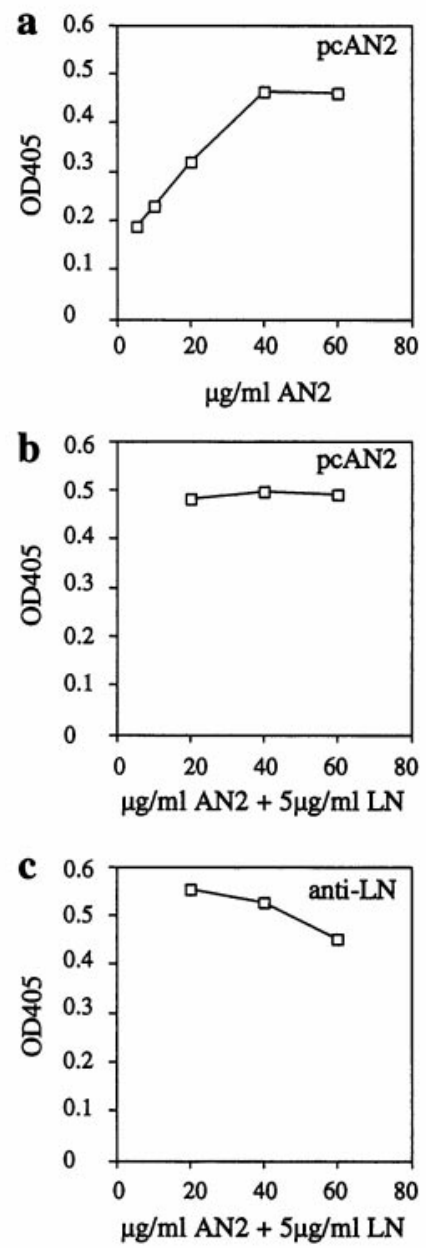

C

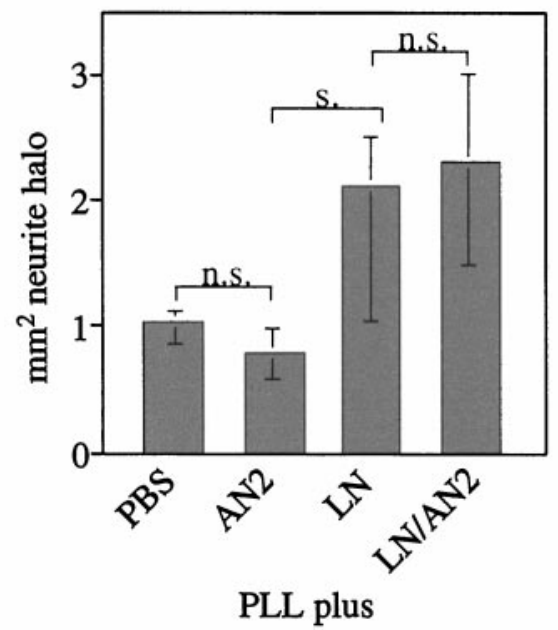

Figure 7. The AN2 protein is neither strongly supportive nor repulsive for neurite outgrowth from DRG explants. $A$, The coating efficiency on PLL-coated cell culture dishes was determined by ELISA. $a$, The binding efficiency of AN2 developed with AN2 polyclonal antibodies ( $p c A N 2)$ is shown. $b$, The binding efficiency of AN2 in the presence of $5 \mu \mathrm{g} / \mathrm{ml} \mathrm{LN}$ developed with AN2 polyclonal antibodies ( $p c A N 2)$ is shown. $c$, The binding efficiency of $\mathrm{LN}$ in the presence of an increasing amount of AN2 developed with LN polyclonal antibodies $($ anti- $L N)$ is shown. The concentration of the protein solutions that gives a saturating coating on PLL dendroglial progenitor cells (Niehaus et al., 1999). The direct observation of migrating cells allowed the determination of the migration distance as well as the migration velocity. Cells of untreated control aggregates migrated at $3.108 \mu \mathrm{m} / \mathrm{hr}$ (median of at least 100 values obtained in three independent experiments), but the migration of cells from polyclonal AN2 antibody-treated aggregates was significantly reduced $(p<0.05)$ to $2.429 \mu \mathrm{m} / \mathrm{hr}$ (median of at least 100 values obtained in three independent experiments).

\section{Increased expression of AN2 in PMP-22-transgenic rats}

The hereditary neuropathy CMT1A in humans is caused in most cases by a duplication of the gene for PMP-22 (Scherer, 1997; Hanemann and Müller, 1998). Lines of transgenic rats overexpressing PMP-22 have been established as an animal model of this human disease (Sereda et al., 1996). Heterozygous transgenic animals display hypomyelination and onion bulb formation resulting from cycles of demyelination and remyelination, characteristic features of the CMT1A disease. In PMP-22-transgenic rats that have been bred to homozygosity, increased numbers of SCs are observed, and virtually all SCs are arrested in a promyelinating state (Sereda et al., 1996; Niemann et al., 2000) (Fig. $8 C$ ). The investigation of nerve biopsies from CMT1A patients and animal models revealed an increased expression of markers of immature SCs such as neural CAM and the p75NTR (Hanemann et al., 1996; Magyar et al., 1996; Müller, 2000; Niemann et al., 2000).

In contrast to the nerve crush where SC expansion is accompanied by axonal degeneration and regrowth, in the PMP-22transgenic rats, SCs expand in the continual presence of axons. We investigated whether this experimental expansion of an immature SC population in the continual presence of axons was accompanied by an increased expression of AN2. The expression level of the AN2 protein in sciatic nerves of heterozygous "CMT rats" and homozygous transgenic animals was analyzed by Western blot and immunofluorescence. Figure $8 A$ shows that both heterozygous (1-yr-old) and homozygous (4-months-old) animals expressed significantly more AN2 than did wild-type animals. The difference in AN2 expression between homozygous and heterozygous animals may be partly age-related, a difference that is reflected in the differing expression of $\alpha$-tubulin. AN2 signals from wild-type littermates are hardly detectable because of the low amounts of protein loaded. Immunofluorescence staining also showed an elevated level of AN2 expression in sciatic nerves of homozygous animals (Fig. $8 B, b$ ) compared with that of the age-matched wild-type littermate (Fig. $8 B, e$ ). No paranodal staining of MAG was observed, and the overall expression of MAG appeared reduced in homozygous animals (Fig. $8 B, c, f$ ). In addition, it can be seen that there appears to be no major increase in

and nitrocellulose (data not shown) was determined to be $40 \mu \mathrm{g} / \mathrm{ml}$ AN2 when coated alone $(a)$ or when mixed with $5 \mu \mathrm{g} / \mathrm{ml} \mathrm{LN}(b)$. In this latter mixture the binding of $\mathrm{LN}$ to the basal substrate was only slightly reduced (c). $B$, DRG explants were cultured for $24 \mathrm{hr}$ on PLL coated with PBS $(a)$, AN2 (b), LN (c), and $\mathrm{LN}$ and $\mathrm{AN} 2(d)$ as described above and subsequently stained with toluidine blue. Scale bars, $100 \mu \mathrm{m}$. $C$, DRG explants were cultured for $24 \mathrm{hr}$ on different substrates, and the neurite halo as a measure of the neurite outgrowth was determined. Vertical bars represent the median with 25 and $75 \%$ fractiles (s., significantly different, $p<0.05$; n.s., not significantly different). One representative experiment is shown. The concentration of the substrates used for coating was 40 $\mu \mathrm{g} / \mathrm{ml} \mathrm{AN} 2,5 \mu \mathrm{g} / \mathrm{ml} \mathrm{LN}$, or a mixture containing $40 \mu \mathrm{g} / \mathrm{ml} \mathrm{AN} 2$ and 5 $\mu \mathrm{g} / \mathrm{ml} \mathrm{LN}$. 
$\mathbf{A}$



B
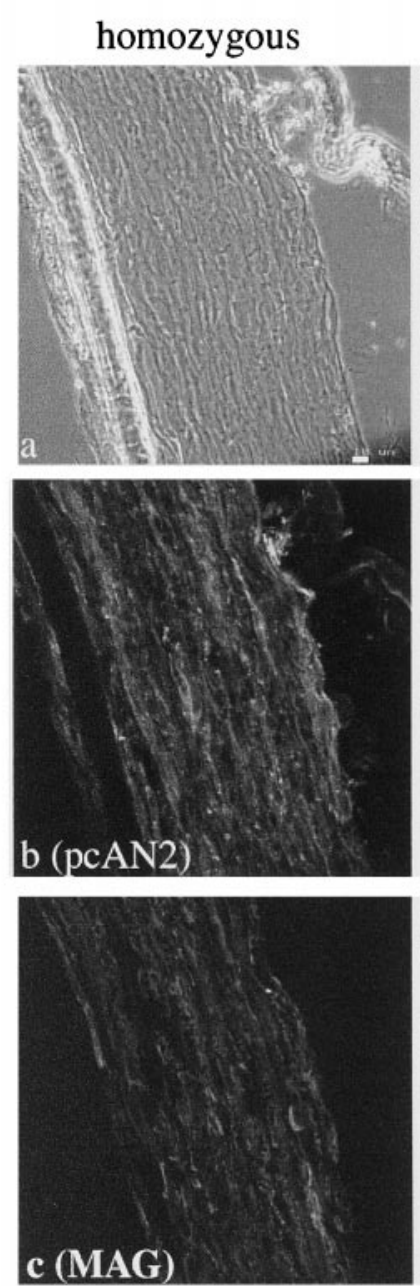
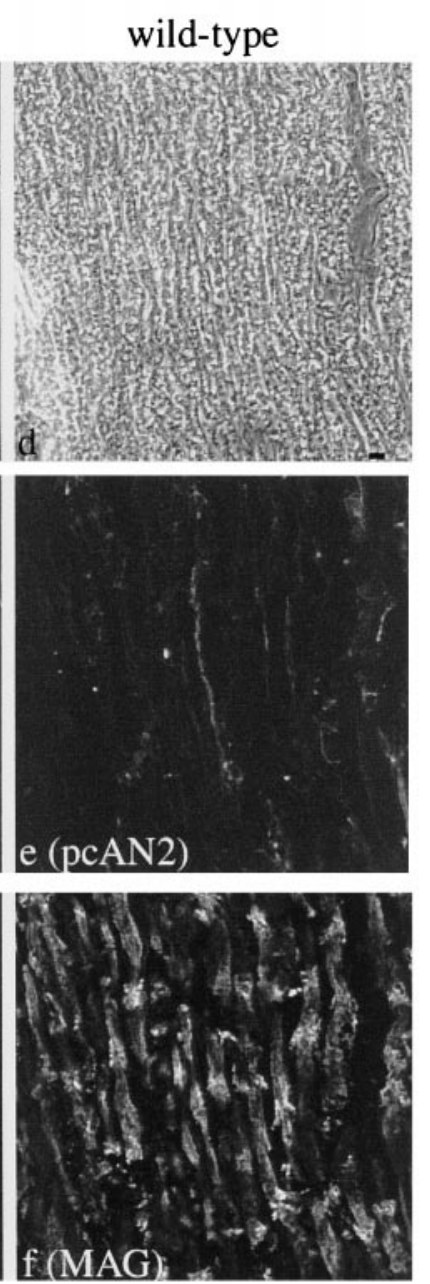

C

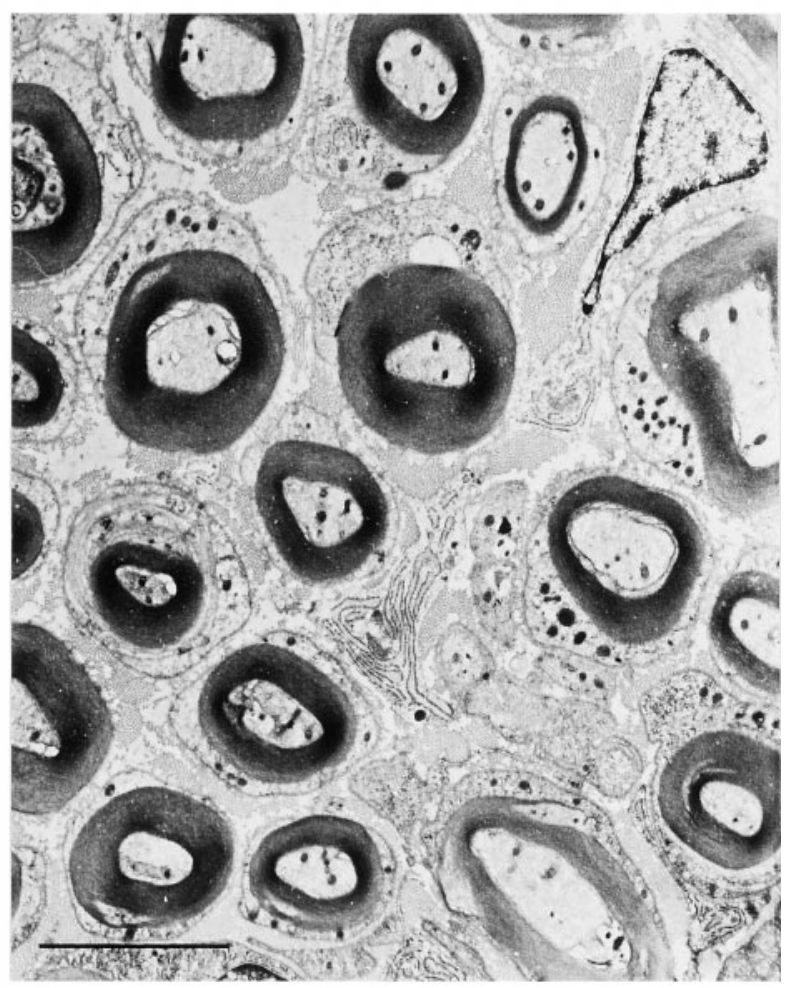

D

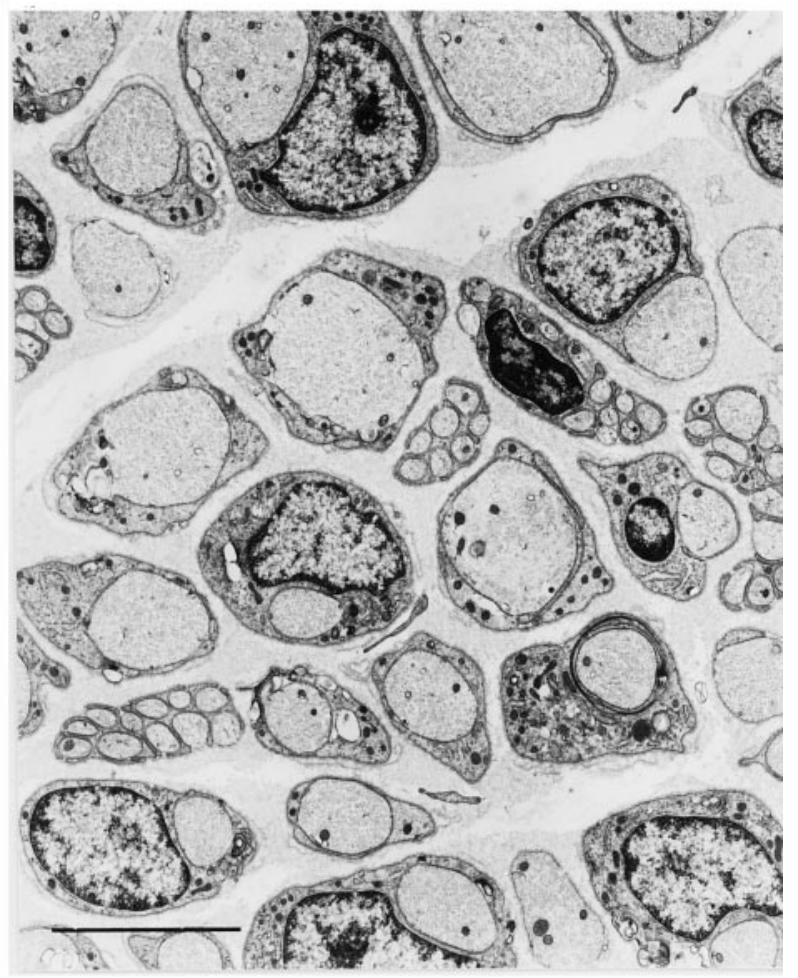

Figure 8. The expression of the AN2 protein in the PMP-22-transgenic rats is increased compared with that in wild-type animals. $A$, Lysates of sciatic nerves of homozygous (ho), heterozygous (he), and wild-type ( $w t)$ PMP-22-transgenic rats (20 $\mu \mathrm{g}$ protein/lane) were separated by gel electrophoresis, blotted, and incubated with AN2 polyclonal antibodies. The same blot was stripped and reprobed with monoclonal antibodies against $\alpha$-tubulin. $B$, Longitudinal cryosections of snap-frozen sciatic nerve from homozygous $(a-c)$ and wild-type $(d-f)$ littermates of the same age (4 months) were stained with AN2 polyclonal antibodies $(b, e)$ and MAG monoclonal antibodies $(c, f) . a$ and $d$ are the corresponding phase-contrast pictures. Single optical sections were analyzed by use of a confocal microscope. $C$, Electron microscopic picture of a sciatic nerve from a wild-type littermate of a PMP-22-transgenic rat shows that the nerve contains mainly myelinated axons. $D$, Electron microscopic picture of a sciatic nerve from a homozygous PMP-22-transgenic rat shows that the nerve mainly contains SCs and axons in a 1:1 relationship and only a few endoneurial fibroblasts, similar to the wild-type littermate $(C)$. Scale bars: $B, 10 \mu \mathrm{m} ; C, D, 5 \mu \mathrm{m}$. 
A $\quad 31 / 61$ matches (50\%)

251910.2 Da Acc. \# 8469184

RATTUS NORVEGICUS.

(X56541) NG2 proteoglycan

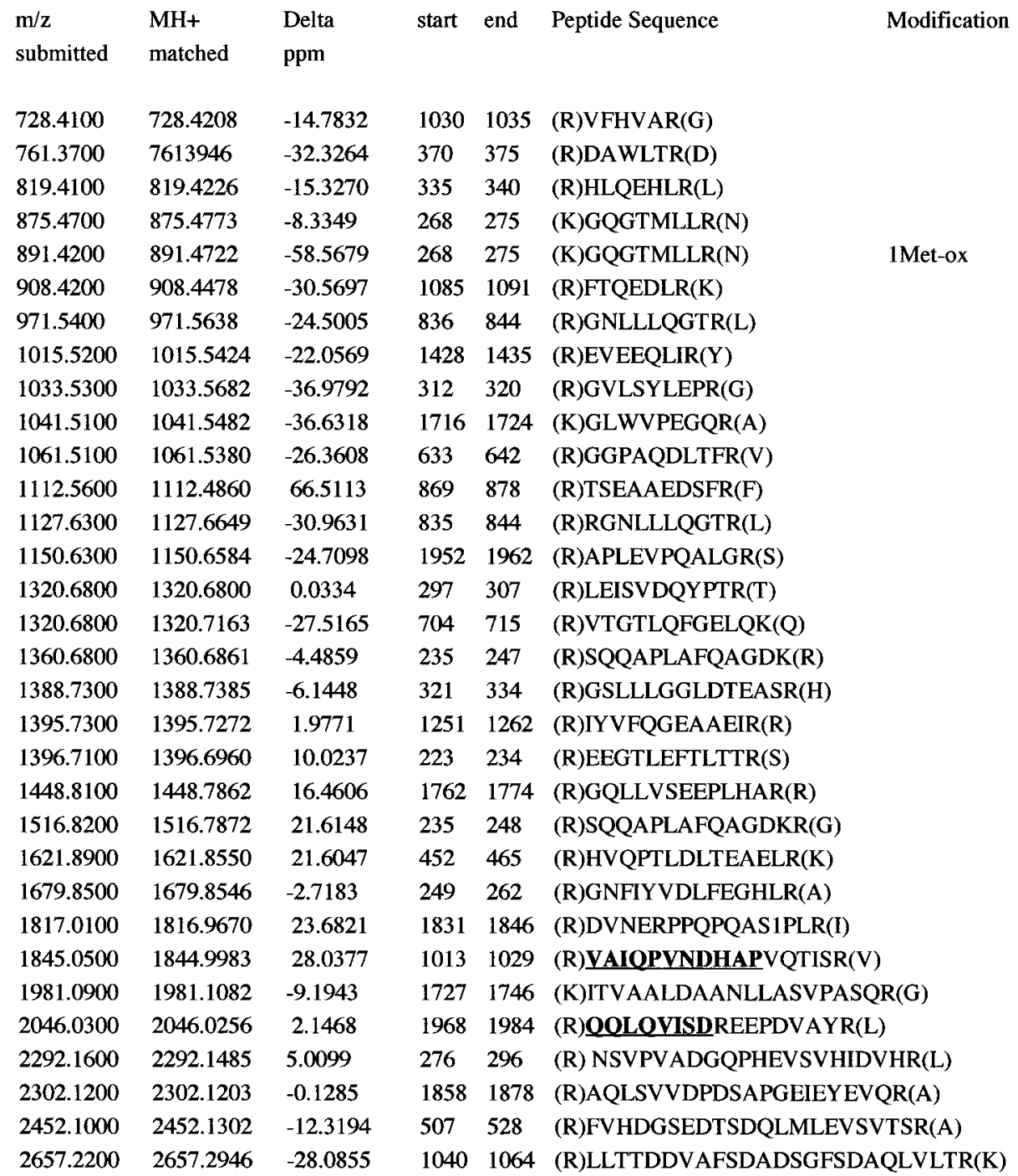

Figure 9. Peptide masses obtained by MALDI MS analysis matching with tryptic fragments of the rat NG2 proteoglycan and distribution of the peptide masses along the amino acid sequence of NG2. $A$, Peptide masses that were obtained by tryptic digestion of the immunoaffinity-purified AN2 protein and subsequent MALDI MS analysis were analyzed with the help of the search program ProFound. Shown are only those peptide masses $(\mathrm{m} / \mathrm{z}$ submit ted) that match with the rat NG2 proteoglycan $(\mathrm{MH}+$ matched $)$. The column headed Delta ppm gives the difference between submitted and matching peptide masses in parts per million ( $\mathrm{ppm}$ ). The amino acid positions of the NG2 peptides are indicated by start and end. The column headed Peptide Sequence is the matching NG2 sequence. Parenthesis indicate the amino acids preceding and following the sequence obtained from the mass determination. Modification indicates that oxidated methionine (Met-ox) residues were also found, yielding two peptide masses matching with one fragment. Peptide sequences obtained by Edman sequencing that matched exactly the published NG2 amino acid sequence are shown bold and underlined. $B$, The peptide masses of the tryptic AN2 fragments are distributed evenly over the entire ectodomain of NG2 [amino acids (aa) 0-2224]. The bottom of the $x$-axis represents a onedimensional projection of the data. No peptide fragments matching the transmembrane (aa 2225-2249) or the cytoplasmic (aa 2250-2326) domain were obtained in the mass spectrum.
B

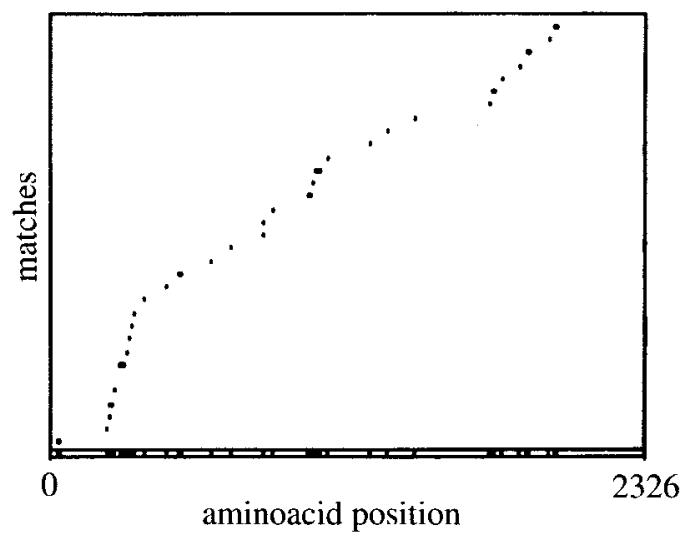




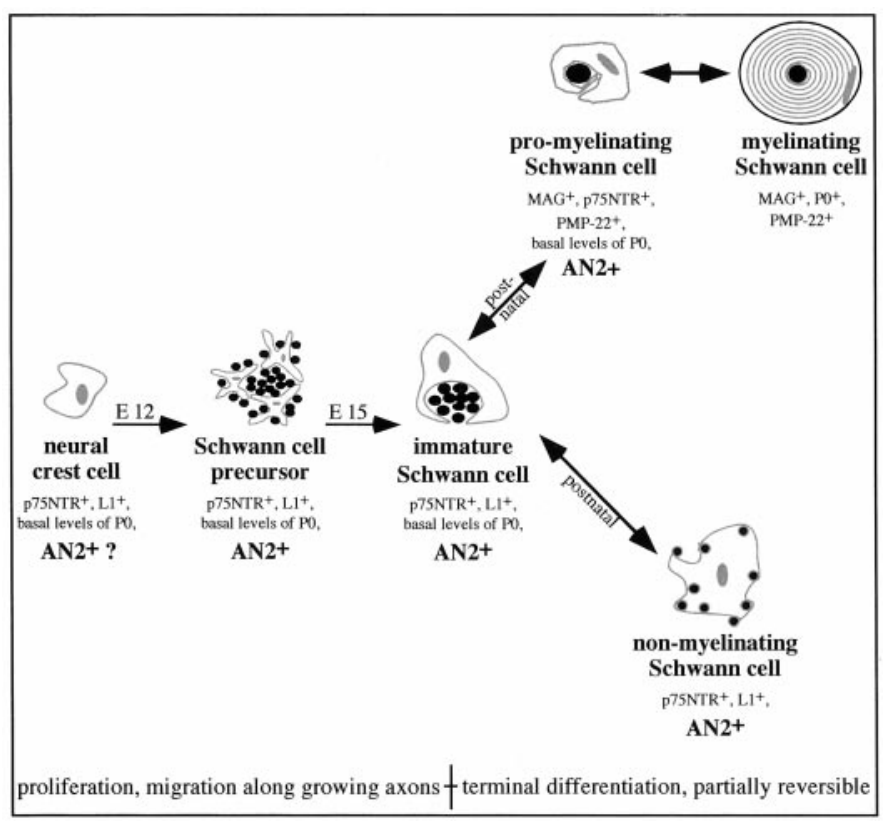

Figure 10. Expression of the AN2 protein in the Schwann cell lineage. The AN2 protein is expressed by immature, promyelinating, and a subset of nonmyelinating SCs. The SC precursor is also AN2 positive. Adapted with modifications from Zorick and Lemke (1996) and Jessen and Mirsky (1999).

the number of endoneurial fibroblasts in nerves of transgenic animals (Fig. 8D) compared with that of wild-type littermates (Fig. $8 C$ ). These results support the hypothesis that the AN2 protein is a marker for immature and nonmyelin-forming SCs and suggest that differentiation of PMP-22-overexpressing SCs in homozygous animals is arrested at an AN2-positive stage.

\section{MALDI MS analysis of immunoaffinity-purified AN2 protein}

A sample of AN2 isolated from P9-P10 mouse brain was digested with chrondroitinase $\mathrm{ABC}$ to release the glucosaminoglycan chains and was separated by SDS gel electrophoresis. The cutout band was then subjected to MALDI MS as described in Materials and Methods. Thirty-one of 61 peptide masses obtained matched the tryptic fragments of the rat NG2 proteoglycan (Nishiyama et al., 1991) (Fig. 9A). These matches were widely distributed over the large ectodomain of NG2 (Fig. 9B). No other significant matches were found corresponding to other proteins. Masses of analyzed peptides with carbohydrate attached cannot be assigned using this technology. This high number of matching peptide masses unambiguously identifies AN2 as the murine homolog of rat NG2. Additionally, two of the purified tryptic fragments were subjected to Edman sequencing. The peptide sequences obtained matched exactly the published NG2 amino acid sequence (Fig. $9 A$, bold, underlined peptide sequences).

\section{DISCUSSION}

The AN2 protein is a marker for precursor, immature, nonmyelinating, and promyelinating Schwann cells

The expression of AN2 by SCs in culture and in vivo suggests that AN2 is a novel marker for a subset of cells in the SC lineage. AN2 staining in vivo and in vitro partly overlaps with p75NTR and L1. In vitro only a few MAG-positive SCs express AN2, indicating that AN2 is expressed by immature but not myelinating SCs. AN2 expression by SCs in $\mathrm{P} 4$ sciatic nerve at the start of myelination is widespread and much stronger than in the adult. Immunogold labeling and electron microscopic analysis of P8 sciatic nerves further demonstrate that AN2 is downregulated relatively late during differentiation of myelin-forming SCs because in contrast to L1 (Martini and Schachner, 1986) it is still expressed by promyelinating SCs (data not shown). In the adult sciatic nerve, AN2 expression is found on small nerve fibers that are doublelabeled with proteins expressed by nonmyelinating SCs such as p75NTR or L1. These latter proteins are also expressed by nonmyelinated axons. Because DRG neurons do not express AN2, we conclude that AN2 is expressed by a subpopulation of nonmyelinating SCs. Additionally, no overlap with MAG in adult sciatic nerve was found, confirming the absence of AN2 from mature, myelinating SCs. We also observed the expression of AN2 in non-neural tissues such as capillaries as well as in fibroblast-like cells of the perineurium (and possibly endoneurium) throughout postnatal sciatic nerve development and in cell culture.

A Western blot of detergent lysates from sciatic nerves confirmed that the expression of the AN2 protein in the PNS is developmentally regulated; the highest expression was detected early postnatally (P0-P8), and the AN2 expression steadily decreased yielding a weaker signal in the adult. Moreover, a subpopulation of AN2 is present as a chondroitin sulfate proteoglycan during early postnatal stages of sciatic nerve development that may endow the protein with additional biological properties. The strong signal for AN2 at birth also suggested that AN2 is expressed during embryonic stages of sciatic nerve development, and immunohistochemical analysis showed that the SC precursor at E12 expresses AN2 (data not shown). Thus, AN2 can be seen as a novel marker for several stages of the SC lineage (Fig. 10). It will be interesting to analyze further whether it also serves as a marker protein for a subpopulation of or all neural crest cells.

\section{The expression of the AN2 protein by immature Schwann cells may be upregulated by direct axon-Schwann cell contact}

Two different experiments suggested that the expression of AN2 is influenced by direct axonal contact. First, SCs express no or very low levels of AN2 when cultured in chemically defined medium or neuron-conditioned medium. AN2 expression by SCs is strongly upregulated in neuron-SC cocultures. In DRG explants the difference in AN2 expression between cells attached to neurites and cells without neuronal contact was also apparent although less pronounced. This implies that soluble neuregulins (such as glial growth factor) that are proliferation, differentiation, and survival factors for SCs (Adlkofer and Lai, 2000) may not suffice to upregulate AN2 expression. Second, we investigated two disease situations in the PNS in which the population of immature SCs expands. In the PMP-22-transgenic rats the expression of $\mathrm{AN} 2$ as well as of other antigens characteristic of immature SCs is upregulated. In these rats SC differentiation is impaired, and in the homozygous rats increased numbers of SCs are apparent. In contrast, after nerve crush the expression of the AN2 protein does not appear to change dramatically in Western blot analysis. Because AN2 is found on several different cell types in the PNS, changes in the expression level by SCs might have been hidden by alterations in AN2 expression on perineurial and endoneurial cells and capillaries. In fact, immunohistochemical analysis of the distal region of crushed nerves showed that many AN2-expressing cells did not stain with SC markers such as 
p75NTR and thus may be fibroblasts. In addition, many p75NTRpositive SCs present in the distal nerve stump 1 week after crush are AN2 negative. Additionally, AN2 is downregulated when the cells upregulate MAG. Thus an initial transient upregulation of AN2 in response to regrowing axons may have been overlooked because this would occur in a very narrow time window. One of the striking differences between these two pathological situations exhibiting expanded populations of immature SCs is the presence of an axon in the PMP-22-transgenic rats but the initial absence of an axon during peripheral nerve regeneration.

The identification of an axonal factor(s) as well as a factor(s) present in FCS that upregulates AN2 expression by SCs would shed new light on the regulation of SC development. The complex regulation of $\mathrm{AN} 2$ expression in the two in vivo pathological situations studied also demonstrates that degeneration and regeneration is not merely a recapitulation of development but that the underlying mechanisms are more complex.

\section{The identity of AN2}

We have discussed previously the molecular identity of the AN2 protein (Niehaus et al., 1999) and its relation to the NG2 proteoglycan and the melanoma-associated chondroitin sulfate proteoglycan (MCSP) (Nishiyama et al., 1991; Levine and Nishiyama, 1996; Pluschke et al., 1996). The monoclonal AN2 antibody binds to the protein core of the molecule rather than to the carbohydrate and stains live cells (Niehaus et al., 1999), thus recognizing an extracellular epitope on the protein. For the MALDI MS analysis and peptide sequences, antigen was purified from P9P10 mouse brain using the monoclonal AN2 antibody. The results demonstrate that AN2 is indeed the mouse homolog of the NG2 proteoglycan because the matches were widely distributed over the large ectodomain of NG2. NG2 has been reported to be expressed in the rat sciatic nerve on perineurial and endoneurial fibroblasts (Morgenstern et al., 1999), although the expression by Schwann cells has not been reported previously. In agreement with our observations, the expression of NG2 in the rat sciatic nerve does not change radically after nerve crush (Morgenstern et al., 1999). Our studies show that the antigen purified from P9-P10 mouse brain using the monoclonal AN2 antibody is a poor substrate for outgrowing neurites from cerebellar (Niehaus et al., 1999) and DRG neurons but is not repulsive and does not inhibit the strongly neurite outgrowth-promoting effect of laminin. The lack of change in expression of AN2 after peripheral nerve lesion is consistent with this observation. NG2 isolated from the B49 cell line has been published as having nonpermissive and repulsive properties (Dou and Levine, 1994).

MCSP is considered the human homolog of rat NG2 (Levine and Nishiyama, 1996; Pluschke et al., 1996; Eisenmann et al., 1999). This proteoglycan is expressed by human melanoma cells, cells that in common with Schwann cells are of neural crest origin. Consistent with the homolog nature of AN2, NG2, and MCSP, our polyclonal and monoclonal AN2 antibodies recognize very similar proteins from a range of human melanoma lines (S. Schneider and J. Trotter, unpublished observations), murine oligodendrocyte precursors, and murine and rat Schwann cells. However, the existence of isoforms or glycosylation variants in different cell types cannot be excluded.

\section{What is the function of the AN2 protein in the PNS?}

The expression pattern of AN2 during PNS development suggests that it may play a role in early stages of SC development, such as the migration of progenitor and immature SCs along outgrowing neurites into the periphery. In the DRG explants that we analyzed, immature AN2-positive SCs can be observed migrating along axonal "highways." Indeed, in agreement with our observations in the CNS in which AN2 plays a role in the migration of oligodendrocyte precursors (Niehaus et al., 1999), polyclonal antibodies against AN2 reduce the migration velocity of the Schwann cell clone SVK1. These observations suggest that the AN2 protein is involved in the migration of immature Schwann cells. In agreement with these observations, MCSP has been shown to stimulate the $\alpha-4 \beta$-1-integrin-mediated adhesion and spreading of melanoma cells (Eisenmann et al., 1999), processes involved in cell migration. NG2 appears to be linked to the actin cytoskeleton (Fang et al., 1999) as would be expected for a transmembrane protein participating in migration. Furthermore, NG2 has been shown to bind to a range of collagen types and other extracellular matrix molecules such as tenascin-C and laminin (Burgh et al., 1996; Tillet et al., 1997). These interactions could influence migration of immature SCs.

The relatively late downregulation of AN2 in the SC lineage by SCs destined to make myelin suggests that it may also be involved in the onset of myelination, such as contributing to SC-axon interactions during ensheathment.

A molecule with such a large extracellular region would be expected to have a range of different partners at different times and places. In addition, the degree of glycosylation may play an important role in modifying the biological activities of the protein. It will be important to define the interaction partners of the protein.

\section{REFERENCES}

Adlkofer K, Lai C (2000) Role of neuregulins in glial cell development. Glia 29:104-111.

Aguayo A, David S, Richardson P, Bray G (1982) Axon elongation in peripheral and central nervous system transplants. Adv Cell Neurobiol 3:215-234.

Amberger VR, Avellanan-Adalid V, Hensel T, Baron-Van Evercooren A, Schwab M (1997) Oligodendrocyte-type 2 astrocyte progenitors use a metalloprotease to spread and migrate on CNS myelin. Eur J Neurosci 9:151-162.

Anton ES, Sandrock Jr AW, Matthew WD (1994) Merosin promotes neurite growth and Schwann cell migration in vitro and nerve regeneration in vivo: evidence using an antibody to merosin, ARM-1. Dev Biol 164:133-146.

Brockes JP, Fields KL, Raff MC (1979) Studies on cultured rat Schwann cells. I. Establishment of purified populations from cultures of peripheral nerve. Brain Res 165:105-118.

Bunge RP (1993) Expanding roles for the Schwann cell: ensheathment, myelination, trophism and regeneration. Curr Opin Neurobiol 3:805-809.

Burgh MA, Tillet E, Timpl R, Stallcup WB (1996) Binding of the NG2 proteoglycan to type VI collagen and other extracellular matrix molecules. J Biol Chem 271:26110-26116.

Davies A (1998) Neuronal survival: early dependence on Schwann cells. Curr Biol 8:R15-R18.

Dou CL, Levine JM (1994) Inhibition of neurite growth by the NG2 chondroitin sulfate proteoglycan. J Neurosci 14:7616-7628.

Einheber S, Milner TA, Giancotti F, Salzer JL (1993) Axonal regulation of Schwann cell integrin expression suggests a role for alpha 6 beta 4 in myelination. J Cell Biol 123:1223-1236.

Eisenmann KM, McCarthy JBM, Simpson MA, Keely PJ, Guan J-L, Tachibana K, Lim L, Manser E, Furcht LT, Iida J (1999) Melanoma chondroitin sulphate proteoglycan regulates cell spreading through Cdc42, Ack-1 and p130 cas. Nat Cell Biol 1:507-513.

Fang X, Burg MA, Barritt D, Dahlin-Huppe K, Nishiyama A, Stallcup WB (1999) Cytoskeletal reorganisation induced by engagement of the NG2 proteoglycan leads to cell spreading and migration. Mol Biol Cell 10:3373-3387.

Fawcett JW, Keynes RJ (1990) Peripheral nerve regeneration. Annu Rev Neurosci 13:43-60.

Hanemann CO, Müller H-W (1998) Pathogenesis of Charcot-MarieTooth 1A (CMT1A) neuropathy. Trends Neurosci 21:282-286.

Hanemann CO, Gabreels-Fasten AA, Müller H-W, Stoll G (1996) Low affinity NGF receptor expression in CMT1A nerve biopsies of different disease stages. Brain 119:1461-1469. 
Jensen ON, Podtelejnikov A, Mann M (1996) Delayed extraction improves specificity in database searches by matrix-assisted laser desorption/ionization peptide maps. Rapid Commun Mass Spectrom 10:1371-1378

Jessen KR, Mirsky R (1999) Schwann cells and their precursors emerge as major regulators of nerve development. Trends Neurosci 22:402-410.

Jessen KR, Brennan A, Morgan L, Mirsky R, Kent A, Hashimoto Y, Gavrilovic J (1994) The Schwann cell precursor and its fate: a study of cell death and differentiation during gliogenesis in rat embryonic nerves. Neuron 12:509-527.

Jung M, Crang AJ, Blakemore WF, Hoppe D, Kettenmann H, Trotter J (1994) In vitro and in vivo characterisation of glial cells immortalised with a temperature sensitive SV40 T large antigen-containing retrovirus. J Neurosci Res 37:182-196.

Jung M, Krämer E, Grzenkowski M, Tang K, Blakemore W, Aguzzi A, Khazaie K, Chlichlia K, Von Blankenfeld G, Kettenmann H, Trotter J (1995) Lines of murine oligodendroglial precursor cells immortalized by an activated neu tyrosine kinase show distinct degrees of interaction with axons in vitro and in vivo. Eur J Neurosci 7:1245-1265.

Laemmli UK (1970) Cleavage of structural proteins during the assembly of the head of bacteriophage T4. Nature 277:680-685.

Lagenaur C, Lemmon V (1987) An L1-like molecule, the 8D9 antigen is a potent substrate for neurite extension. Proc Natl Acad Sci USA 84:7753-7757.

Le Douarin N, Dulac C, Dupin E, Cameron-Curry P (1991) Glial cell lineages in the neural crest. Glia 4:175-184.

Lemmon V, Farr KL, Lagenaur C (1989) L1-mediated axon outgrowth occurs via a homophilic binding mechanism. Neuron 2:1597-1603.

Levine JM, Nishiyama A (1996) The NG2 chondroitin sulfate proteoglycan: a functional proteoglycan associated with immature cells. Perspect Dev Neurobiol 3:245-259.

Lipman DJ, Pearson WR (1985) Rapid and sensitive protein similarity searches. Science 227:1435-1441.

Magyar J, Martini R, Ruelicke T, Aguzzi A, Adlkofer K, Dembic Z, Zielasek J, Toyka K, Suter U (1996) Impaired differentiation of Schwann cells in transgenic mice with increased PMP-22 gene dosage. J Neurosci 16:5351-5360.

Martini R, Schachner M (1986) Immunoelectron microscopic localization of neural cell adhesion molecules (L1, N-CAM and MAG) and their shared carbohydrate epitope and myelin basic protein in developing sciatic nerve. J Cell Biol 103:2439-2448.

Martini R, Schachner M, Faissner A (1990) Enhanced expression of the extracellular matrix molecule $\mathrm{J} 1 /$ tenascin in the regenerating adult mouse sciatic nerve. J Neurocytol 19:601-616.

McLean IW, Nakane PK (1974) Periodate-lysine-paraformaldehyde fixative: a new fixative for immunoelectron microscopy. J Histochem Cytochem 22:1077-1083.

Meier C, Parmantier E, Brennan A, Mirsky R, Jessen KR (1999) Developing Schwann cells acquire the ability to survive without axons by establishing an autocrine circuit involving insulin-like growth factor, neurotrophin-3, and platelet-derived growth factor-BB. J Neurosci 19:3847-3859.

Mirsky R, Jessen KR (1996) Schwann cell development, differentiation and myelination. Curr Opin Neurobiol 6:89-96.
Morgan L, Jessen KR, Mirsky R (1991) The effects of cAMP on differentiation of cultured Schwann cells: progression of an early phenotype $(\mathrm{O} 4+)$ to a myelin phenotype $(\mathrm{P} 0+$, GFAP-, N-CAM-, NGFreceptor-) depends on growth inhibition. J Cell Biol 112:457-467.

Morgenstern DA, Asher RA, Levine JM, Fawcett JW (1999) Expression of the chondroitin sulfate proteoglycan NG2 in normal and regenerating sciatic nerve. Soc Neurosci Abstr 25:1264.

Müller HW (2000) Tetraspan myelin protein PMP22 and demyelinating peripheral neuropathies: new facts and hypothesis. Glia 29:182-185.

Niehaus A, Stegmüller J, Diers-Fenger M, Trotter J (1999) Cell-surface glycoprotein of oligodendrocyte progenitors involved in migration. J Neurosci 19:4948-4961.

Niemann S, Sereda MW, Suter U, Griffiths IR, Nave KA (2000) Uncoupling of myelin assembly and Schwann cell differentiation by transgenic overexpression of peripheral myelin protein 22. $\mathbf{J}$ Neurosci 20:4120-4128.

Nishiyama A, Dahlin KJ, Prince JT, Johnstone SR, Stallcup WB (1991) The primary structure of NG2, a novel membrane-spanning proteoglycan. J Cell Biol 114:359-371.

Pluschke G, Vanek M, Evans A, Dittmar T, Schmid P, Itin P, Filardo EJ, Reisfeld RA (1996) Molecular cloning of a human melanoma associated chondroitin sulfate proteoglycan. Proc Natl Acad Sci USA 93:9710-9715.

Poltorak M, Sadoul R, Keilhauer G, Landa C, Fahrig T, Schachner M (1987) The myelin-associated glycoprotein (MAG), a member of the L1/HNK-1 family of neural cell adhesion molecules, is involved in neuron-oligodendrocyte and oligodendrocyte-oligodendrocyte interaction. J Cell Biol 105:1893-1899.

Rathjen FG, Schachner M (1984) Immunocytochemical and biochemical characterisation of a neuronal cell surface component (L1 antigen) which is involved in cell adhesion. EMBO J 3:1-10.

Scherer SS (1997) The biology and pathobiology of Schwann cells. Curr Opin Neurol 10:386-397.

Schnitzer J, Schachner M (1981) Developmental expression of cell typespecific markers in mouse cerebellar cells. J Neuroimmunol 1:471-487.

Seilheimer B, Schachner M (1988) Studies of adhesion molecules mediating interactions between cells of the peripheral nervous system indicate a major role for L1 in mediating sensory neuron growth on Schwann cells in culture. J Cell Biol 107:341-351.

Sereda M, Griffiths I, Pühlhofer A, Stewart H, Rossner M, Zimmermann F, Magyar JP, Schneider A, Hund E, Meinck H-M, Suter U, Nave K-A (1996) A transgenic rat model of Charcot-Marie-Tooth disease. Neuron 16:1049-1060.

Tillet E, Ruggiero F, Nishiyama A, Stallcup WB (1997) The membranespanning proteoglycan NG2 binds to collagens V and VI through the central nonglobular domain of its core protein. J Biol Chem 272:10769-10776.

Vabnick I, Shrager P (1998) Ion channel redistribution and function during development of the myelinated axon. J Neurobiol 37:80-96.

Witt A, Brady ST (2000) Unwrapping new layers of complexity in axon/ glia relationships. Glia 29:112-117.

Zorick TS, Lemke G (1996) Schwann cell differentiation. Curr Opin Cell Biol 8:870-876. 